University of Nebraska - Lincoln

DigitalCommons@University of Nebraska - Lincoln

1999

\title{
Abrupt along-strike change in tectonic style: San Andreas fault zone, San Francisco Peninsula
}

\author{
Mary Lou Zoback \\ U.S. Geological Survey, marylouz@stanford.edu \\ Robert C. Jachens \\ U.S. Geological Survey \\ Jean A. Olson \\ Timble Navigation Company
}

Follow this and additional works at: https://digitalcommons.unl.edu/usgsstaffpub

Part of the Earth Sciences Commons

Zoback, Mary Lou; Jachens, Robert C.; and Olson, Jean A., "Abrupt along-strike change in tectonic style: San Andreas fault zone, San Francisco Peninsula" (1999). USGS Staff -- Published Research. 467. https://digitalcommons.unl.edu/usgsstaffpub/467

This Article is brought to you for free and open access by the US Geological Survey at DigitalCommons@University of Nebraska - Lincoln. It has been accepted for inclusion in USGS Staff -- Published Research by an authorized administrator of DigitalCommons@University of Nebraska - Lincoln. 


\title{
Abrupt along-strike change in tectonic style: San Andreas fault zone, San Francisco Peninsula
}

\author{
Mary Lou Zoback, Robert C. Jachens, and Jean A. Olson ${ }^{1}$ \\ U.S. Geological Survey, Menlo Park, California
}

\begin{abstract}
Seismicity and high-resolution aeromagnetic data are used to define an abrupt change from compressional to extensional tectonism within a 10- to $15-\mathrm{km}$-wide zone along the San Andreas fault on the San Francisco Peninsula and offshore from the Golden Gate. This 100-km-long section of the San Andreas fault includes the hypocenter of the $M_{w}=7.81906$ San Francisco earthquake as well as the highest level of persistent microseismicity along that $\sim 470-\mathrm{km}$-long rupture. We define two distinct zones of deformation along this stretch of the fault using well-constrained relocations of all post1969 earthquakes based a joint one-dimensional velocity/hypocenter inversion and a redetermination of focal mechanisms. The southern zone is characterized by thrust- and reverse-faulting focal mechanisms with NE trending $P$ axes that indicate "fault-normal" compression in 7- to 10-km-wide zones of deformation on both sides of the San Andreas fault. A 1- to 2-km-wide vertical zone beneath the surface trace of the San Andreas is characterized by its almost complete lack of seismicity. The compressional deformation is consistent with the young, high topography of the Santa Cruz Mountains/Coast Ranges as the San Andreas fault makes a broad restraining left bend $\left(\sim 10^{\circ}\right)$ through the southernmost peninsula. A zone of seismic quiescence $\sim 15 \mathrm{~km}$ long separates this compressional zone to the south from a zone of combined normal-faulting and strike-slipfaulting focal mechanisms (including a $M_{L}=5.3$ earthquake in 1957) on the northernmost peninsula and offshore on the Golden Gate platform. Both linear pseudogravity gradients, calculated from the aeromagnetic data, and seismic reflection data indicate that the San Andreas fault makes an abrupt $\sim 3-\mathrm{km}$ right step less than $5 \mathrm{~km}$ offshore in this northern zone. A similar right-stepping (dilatational) geometry is also observed for the subparallel San Gregorio fault offshore. Persistent seismicity and extensional tectonism occur within the San Andreas right stepover region and at least 15 $\mathrm{km}$ along-strike both to the SE and NW. The 1906 San Francisco earthquake may have nucleated within the San Andreas right stepover, which may help explain the bilateral nature of rupture of this event. Our analysis suggests two seismic hazards for the San Francisco Peninsula in addition to the hazard associated with a $M=7$ to 8 strike-slip earthquake along the San Andreas fault: the potential for $a M \approx 6$ normal-faulting earthquake just 5-8 km west of San Francisco and a $M=6+$ thrust faulting event in the southern peninsula.
\end{abstract}

\section{Introduction}

Approximately $100 \mathrm{~km}$ southwest of the San Francisco Peninsula the very linear central California segment of the San Andreas fault bifurcates, with the westerly strand heading toward the peninsula as the San Andreas fault proper (Figure 1). The Hayward-Calaveras fault systems in the East Bay form an eastern, more northerly striking strand. Together these two strands account for roughly $\sim 32 \mathrm{~mm} \mathrm{yr}^{-1}$ right-lateral shear, or approximately $85 \%$ of the plate motion east of the Sierra Nevada [Working Group on Northern California Earthquake Potential, 1996; Williams et al., 1994]. A third strike-slip fault zone subparallel to the San Andreas fault, the San Gregorio fault, crosses the westernmost part of the peninsula and the shelf offshore from the Golden Gate (Golden Gate Platform).

\footnotetext{
${ }^{1}$ Now at Trimble Navigation Company, Sunnyvale, California.
}

This paper is not subject to U.S. copyright. Published in 1999 by the American Geophysical Union.

Paper number 1998JB900059.
This fault is part of the San Gregorio-Hosgri fault system, a mostly late Tertiary, plate boundary fault zone with a cumulative offset of $100-150 \mathrm{~km}$, that extends from Point Sal in southern California and merges with the San Andreas fault on the Golden Gate platform [Graham and Dickinson, 1978; Clark et al., 1984]. Geologic data, including trenching of the San Grcgorio fault, indicate multiple Holocene surface rupturing events and a slip rate of $\sim 5 \mathrm{~mm} \mathrm{yr}^{-1}$ [Simpson et al., 1997; Working Group on Northern California Earthquake Potential, 1996].

Four significant historic earthquakes have occurred on the San Francisco Peninsula (Figure 1): $(1)$ a $M_{w} \approx 6.8-7.5$ event in 1838 on the central peninsula, which on the basis of firsthand accounts of the surface rupture appears to be a rightlateral strike-slip event on the San Andreas fault [Louderback, 1947; Ellsworth, 1990; Tuttle and Sykes, 1992; Toppozada and Borchardt, 1998; Bakun, 1999]; (2) the $M_{w}=7.81906$ San Francisco earthquake with an epicenter probably located somewhere near where the San Andreas fault goes offshore, south of the Golden Gate [Bolt, 1969; Boore, 1981; Wald et al., 


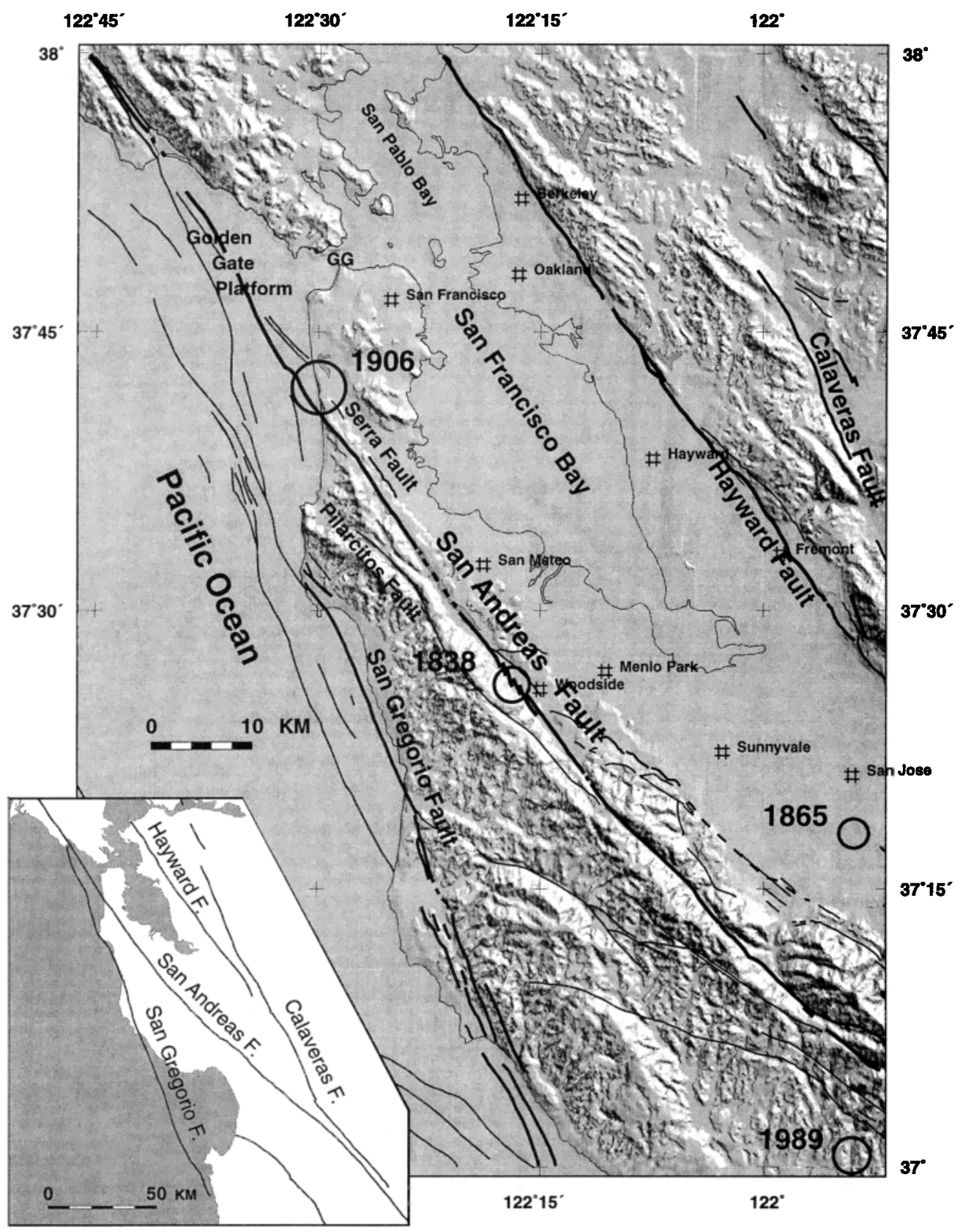

Figure 1. Shaded topography map showing Quaternary faults in the greater San Francisco Bay area [Bortugno et al., 1992]. The inset shows major strike-slip fault systems in central California. Large circles indicate approximate epicenters of large historic earthquakes. The location of the 1838 epicenter is unknown; it is plotted on the central peninsula near the center of the assumed rupture.

1993; Thatcher et al., 1997]; (3) the $M_{w}=6.91989$ Loma Prieta earthquake on the southernmost peninsula; and (4) a $M \approx 6.5$ event in 1865 probably located near the city of San Jose, which may have been a thrust or oblique thrust event similar to the 1989 Loma Prieta earthquake and possibly not on the San Andreas fault [Tuttle and Sykes, 1992; Jaumé and Sykes, 1996]. While there is considerable controversy about the magnitude of the 1838 event (estimates range from 6.8 to 7.5 [Bakun, 1999; Toppozada and Borchardt, 1998]), at a minimum the 1838 and 1906 earthquakes sum to about two thirds of the expected moment release for the entire Pacific-North Ameri- can plate boundary (including the East Bay fault systems) for the past 160 years [Bakun, 1999].

Whereas geologic, historic earthquake, and geodetic data all indicate that the dominant style of deformation in the San Francisco Peninsula region is right-lateral strike-slip faulting, changes in geometry of the San Andreas fault system in the vicinity of the peninsula coincide with marked along-strike variations in its geomorphic and topographic expression. In crossing the southern peninsula, the San Andreas fault undergoes a broad bend to the left (a 12- to $15-\mathrm{km}$ westward bend over $\sim 90-\mathrm{km}$ length of fault, resulting in a $\sim 10^{\circ}-12^{\circ}$ compres- 
sional "restraining" bend), analogous to the "Big Bend" in the Transverse Ranges of southern California but on a much smaller scale. As in the Big Bend region in southern California, there is a zone of uplift (25-30 km wide) straddling the San Andreas fault that is particularly pronounced on the SW side, forming the Santa Cruz Mountains. The 1989 Loma Prieta event occurred within this bend region and exhibited nearly equal components of right lateral strike-slip and reverse fault motion $\left(\right.$ rake $=140^{\circ}$ ) $[$ Oppenheimer, 1990]. Both geodetic data and surface deformation features suggest that this event did not occur on the same portion of San Andreas fault that ruptured in 1906 [Thatcher et al., 1997; Prentice and Schwartz, 1991; Segall and Lisowski, 1990]. However, this event drew attention to the seismic potential of the convergent component of plate motion in the Bay area.

On the central and northern peninsula the active strand of the San Andreas fault is straight, with an average trend of $\mathrm{N} 36^{\circ} \mathrm{W}$, only $\sim 1^{\circ}$ oblique to the $\mathrm{N} 34.5^{\circ} \mathrm{W}$ direction of relative Pacific-westernmost North American plate motion [Argus and Gordon, 1991]. On the northernmost peninsula the zone of uplift adjacent to the San Andreas fault becomes much narrower (total width of 5-10 km) and topographically more subdued than to the south. Although Quaternary thrust faults subparallel to the San Andreas fault are mapped all along the peninsula, the number and cumulative offset on these thrusts observed at the surface greatly decrease north of about $37^{\circ} 25^{\prime}$ [Aydin and Page, 1984]. A 2- to 3-km right step or bend in the San Andreas fault system can be inferred across the Golden Gate platform by projecting onland traces of the San Andreas fault from the north and south. A right step in a right-lateral strike-slip system implies a component of extension. It may not be a coincidence that the elevation of the San Andreas fault decays northward on the peninsula toward the Golden Gate platform, where it presently lies below sea level.

The subject of this paper is a seismotectonic and seismic hazard analysis of the complex 100-km-long stretch of the San Andreas fault extending NW from the north end of the Loma Prieta aftershock zone to the Point Reyes Peninsula, just north of the Golden Gate platform. In addition to the along-strike variations in fault geometry and geomorphic expression discussed above, this section of the San Andreas fault also includes the 1906 epicenter as well as some of the highest levels of microseismicity anywhere along the 470-km-long 1906 rupture (including a $M_{L}=5.31957$ earthquake just south of San Francisco (Figure 1)). Significantly, this stretch of the San Andreas fault also represents the only fault segment in the United States with a proven potential for a $M_{w}=7.8$ earthquake that directly transects a major urban area. The objectives of our study are to (1) use accurate microearthquake locations and well-constrained earthquake focal mechanisms to determine the relationship between deformation on the San Andreas fault proper and that within in the crustal blocks directly adjacent to the fault, (2) constrain the geometry of faulting offshore using high-resolution aeromagnetic data, (3) analyze, in light of the along-strike geometric and tectonic variations, possible seismic hazard and segmentation implications for strike-slip faulting along the San Andreas fault, and (4) evaluate the long-term seismic hazard potential of simultaneously active, subparallel normal and thrust faults located directly adjacent to the SAF and separated along strike by only 15-20 km. The 1989 Loma Prieta earthquake and aftershock zone at the southernmost end of the peninsula are described only briefly in terms of seismicity patterns observed directly to the north; for more information on this event the reader is referred to Reasenberg [1997], Simpson [1994], Spudich [1996], and Wells and Vidale [1999].

\section{Offshore Fault Locations Inferred From Aeromagnetic Data}

Only limited information has been available on the morphology of the San Andreas fault offshore on the Golden Gate platform. The lack of a clear fault trace on the seafloor in high-resolution seismic profiling [Cooper, 1973] as well as the lack of aligned offset features on detailed (1-m contour) bathymetry maps (T. E. Chase, U.S. Geological Survey (USGS), written communication, 1994) indicates that sedimentary processes on the shelf outpace tectonic processes in determining geomorphic expression of the fault zone. In fact, the coastline where the San Andreas fault cuts offshore is one of the straightest segments of the California coastline because of the combination of easily erodible Pliocene-Quaternary sediments forming beach cliffs and swift, long-shore currents.

We used high-resolution aeromagnetic data to help detail the geometry of San Andreas fault offshore in the region of the inferred right bend or step-over (Plate 1). These data contain prominent anomalies whose edges are, in many cases, concealed fault traces. The aeromagnetic data are shown in Plate 1 and were collected in 1994 and 1996 with fixed-wing aircraft along flight lines $500 \mathrm{~m}$ apart at a nominal height between $250 \mathrm{~m}$ and $300 \mathrm{~m}$ above the surface of the Earth or ocean. For details of the data collection and reduction techniques, see Jachens and Zoback [1999].

Offshore extensions of the San Andreas and San Gregorio faults appear to bound, in map view, a triangular- or wedgeshaped body characterized by a magnetic high (Plate 1). A third fault, the Pilarcitos fault, which lies between the San Gregorio and San Andreas faults forms the southern boundary of this block. The Pilarcitos fault locally forms the geologic boundary between late Mesozoic Franciscan forearc assemblage to the northeast and primarily granitic Salinian rocks to the southwest, just as the San Andreas fault does in central California. The Pilarcitos is believed to represent an abandoned strike-slip portion of the plate boundary $[B r a b b$ and Pampeyan, 1983; Wagner et al., 1991; Page, 1990, 1992; Griscom and Jachens, 1989]. The magnetic high in the wedge-shaped block (here called the Pilarcitos block) indicates that maficrich Franciscan rocks within this block generally are more magnetic than granitic rocks of the Salinian block, southwest of the San Gregorio and Pilarcitos faults, as well as the rocks of the predominately Franciscan Central Belt northeast of the San Andreas fault [Blake et al., 1984]. Because the three faults bound the magnetic Pilarcitos block, their concealed positions in the offshore were determined by defining the edges of the magnetic rocks that comprise the block. Identifying the precise locations of the fault traces from the contoured data shown in Plate 1 is difficult because of the complex magnetic anomalies that result from the dipole nature of magnetic sources.

We inferred the offshore locations of the fault traces by means of a numerical technique utilizing a linear filter, the pseudogravity transform [Baranov, 1957] that removes the magnetic dipole effect and converts a magnetic anomaly to an equivalent gravity anomaly by assuming a constant ratio of magnetization to density. The maximum horizontal gradients of a gravity anomaly produced by a shallowly buried body lie nearly over the sides of the body, particularly if the sides dip 
steeply [Cordell and Grauch, 1985; Blakely and Simpson, 1986]. Therefore the maximum horizontal gradients of the pseudogravity anomaly (transformed magnetic anomaly) can be used to define the locations of the lateral boundaries of the magnetic source body. We modified this technique slightly by applying the maximum gradient analysis not to the simple pseudogravity transformation, but rather to the difference between the transformed magnetic data and those same data upward continued to $200 \mathrm{~m}$. This differencing is equivalent to using a high-pass filter; it focused the procedure on the shallowest parts (upper $\sim 2 \mathrm{~km}$ ) of the magnetic bodies. The inferred shallow magnetic edge boundaries (defined by local maxima in the horizontal pseudogravity gradient) are shown as small "plus" symbols on Plates 1 and 2. Spatial resolution of the location of the inferred magnetic boundaries is probably better than $100 \mathrm{~m}$ based on our ability to accurately locate cultural features such as bridges and large buildings.

We have highlighted on Plate 2 those magnetic boundaries that we interpret to represent the concealed traces of the Pilarcitos, San Gregorio, and San Andreas faults offshore on the Golden Gate platform. We selected these specific magnetic boundaries from the total set of possible choices because (1) they define the lateral boundaries of the magnetic basement rocks that constitute the fault-bounded Pilarcitos block; (2) for the San Andreas and Pilarcitos faults, they represent offshore continuations of the onshore magnetic boundaries that coincide with mapped fault traces across which magnetic basement rocks are juxtaposed against nonmagnetic basement rocks; and (3) for the San Gregorio fault, these magnetic boundaries not only occupy the proper structural location at the edge of the Pilarcitos block, but they are the only long, straight, continuous boundaries that lie within the zone previously defined as the San Gregorio fault zone. The lack of detailed correlation between our fault picks and the existing fault mapping offshore (black lines on Plate 2) is probably due to the fact that previous fault mapping was based on interpretation of relatively low resolution magnetic data and very sparsely distributed marine seismic profiling [McCulloch, 1987].

The northernmost part of the San Andreas fault on the San Francisco Peninsula can be traced by its associated magnetic boundary out to sea on strike NNW for a distance of $6 \mathrm{~km}$ (Plate 2), at which point the magnetic anomaly changes character and the fault projects into the center of the magnetic high that characterizes the Pilarcitos block (Plate 1). Similarly, north of the Golden Gate, the eastern mapped strand of the San Andreas fault at Bolinas Lagoon can be traced offshore by its associated magnetic boundary on strike in a straight line SSW for a distance of $>20 \mathrm{~km}$, to the shoreline of the peninsula at Lake Merced (Plate 1). The two strands do not join, but rather define a right step of $3 \mathrm{~km}$ in the fault system just offshore from Lake Merced.

Cooper [1973] used disruption of the youngest sediments (upper $\sim 5 \mathrm{~m}$ ) imaged on shallow, high-resolution seismic reflection data to identify the "recent trace" of the San Andreas fault offshore from the Golden Gate. He detected an eastward offset in the San Andreas fault, which he mapped as an abrupt bend in the projected onshore portion of the San Andreas. His abrupt right bend in the San Andreas trace occurs in the same area that the magnetic data indicate an offset $3 \mathrm{~km}$ to the $\mathrm{NE}$ (see Plate 2). Cooper's easternmost "recent trace" of the San Andreas fault coincides within $500 \mathrm{~m}$ with our inferred offset segment of the San Andreas fault, remarkable agreement since we do not have precise locations of Cooper's data but only picks from a page size figure. Cooper [1973] also delineated a distinct, somewhat sinuous 20-km-long, 2- to 3-km-wide "San Andreas" graben sitting on top of a broader basin between the San Andreas and San Gregorio faults; the boundaries of this youngest graben correlate well with our newly defined offshore fault traces (Plate 2, inset). Further confirmation of the right step in the San Andreas fault comes from reflections from a near-vertical fault identified by Hole et al. [1996] on a marine seismic profile out the Golden Gate. They interpreted these reflections as coming from depths of 3-7 km on a near-vertical San Andreas fault that coincided at the surface with Cooper's [1973] eastward trace of the San Andreas. These reflections were not compatible with a San Andreas location corresponding to a simple NW projection of the onland fault trace shown in Figure 1. In addition, Cooper mapped a subtle left bend in the NW end of the "recent trace" of the San Andreas (Plate 2, inset) in the region SW of Bolinas Lagoon. The left bend itself is not reflected in the magnetic data, but both ends of Cooper's fault segment north and south of the bend coincide with linear magnetic boundaries (Plate 2, inset).

The magnetic data also suggest that the offshore portion of the San Gregorio fault consists of two main, partly overlapping right-stepping strands, with possibly other parallel but less well defined strands. The westernmost strand is remarkably straight for a distance of $>20 \mathrm{~km}$, from a point $\sim 7 \mathrm{~km}$ north of Half Moon Bay northward to a point nearly opposite the Golden Gate. Near the north end of this strand, the San Gregorio fault steps right about $1.5 \mathrm{~km}$, to a slightly curved, more eastern strand that continues north for an additional $15 \mathrm{~km}$. This eastern strand bends west near its north end, eventually paralleling the San Andreas fault, about $2.5 \mathrm{~km}$ to the southwest of Bolinas Lagoon, but never joining it. The two main strands of the San Gregorio fault overlap for a distance of at least $6 \mathrm{~km}$ (and possibly as much as $12 \mathrm{~km}$ ) at the right step. The Pilarcitos fault can also be traced offshore for a distance of 7-8 km, bending northward near its western end to merge with the San Gregorio fault.

\section{Earthquake Relocation Procedure}

To improve the quality and precision of earthquake locations for the San Francisco Peninsula region, we relocated all magnitude $>1.0$ earthquakes that had previously been routinely located by the USGS Northern California Seismic Network (NCSN; see Oppenheimer et al. [1993] for a description of standard processing). The relocation procedure was carried out in two steps and utilized VELEST, a joint least squares inversion procedure that minimizes traveltime residuals [Ellsworth, 1977; Roecker, 1981]. First, a local best fitting onedimensional (1-D) velocity model was determined; then station corrections were determined for stations both within and adjacent to the study area. The area of relocated events is outlined by the inner small rectangles in Figure 2.

The starting velocity model for the inversion (Peninsula model in Figure 3) was based on a refraction velocity model for a NW trending profile along the peninsula generally coinciding with the San Andreas fault zone [Catchings and Kohler, 1996]. From this starting model a best fitting 1-D velocity model was determined using only stations within the inner rectangles in Figure 4 and about 200 events including (1) 158 local earthquakes with floating (unconstrained) hypocenters, (2) numerous calibration explosions and quarry blasts with known locations, and (3) 15 moderate to regional $(M \geq 5.0)$ earthquakes 

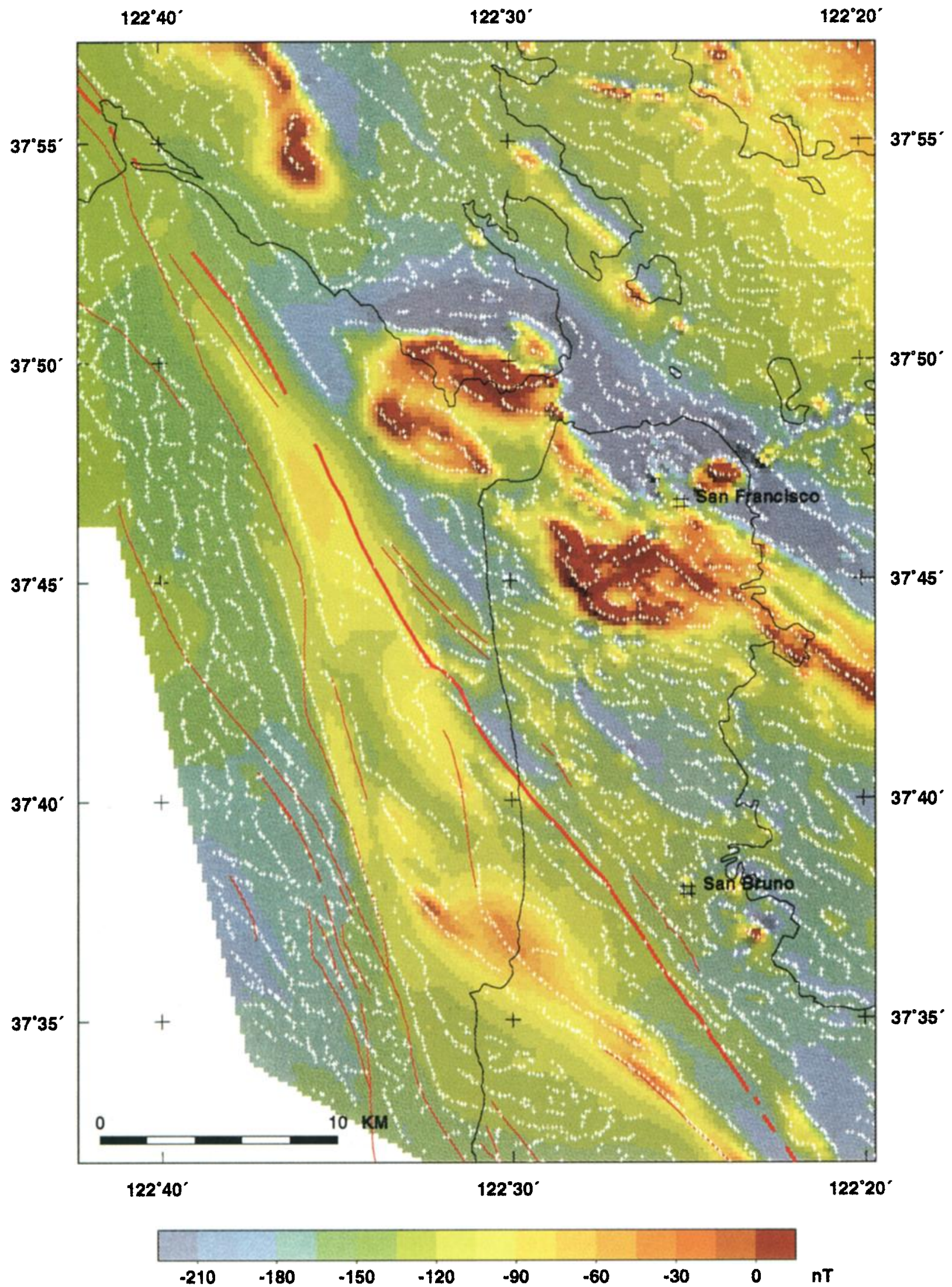

Plate 1. New high-resolution aeromagnetic map of San Francisco Bay area. Quaternary faults from Bortugno et al. [1992] are shown in red. Small white pluses indicate maximum horizontal gradient of the short wavelength component of the pseudo-gravity field (see text for explanation). 


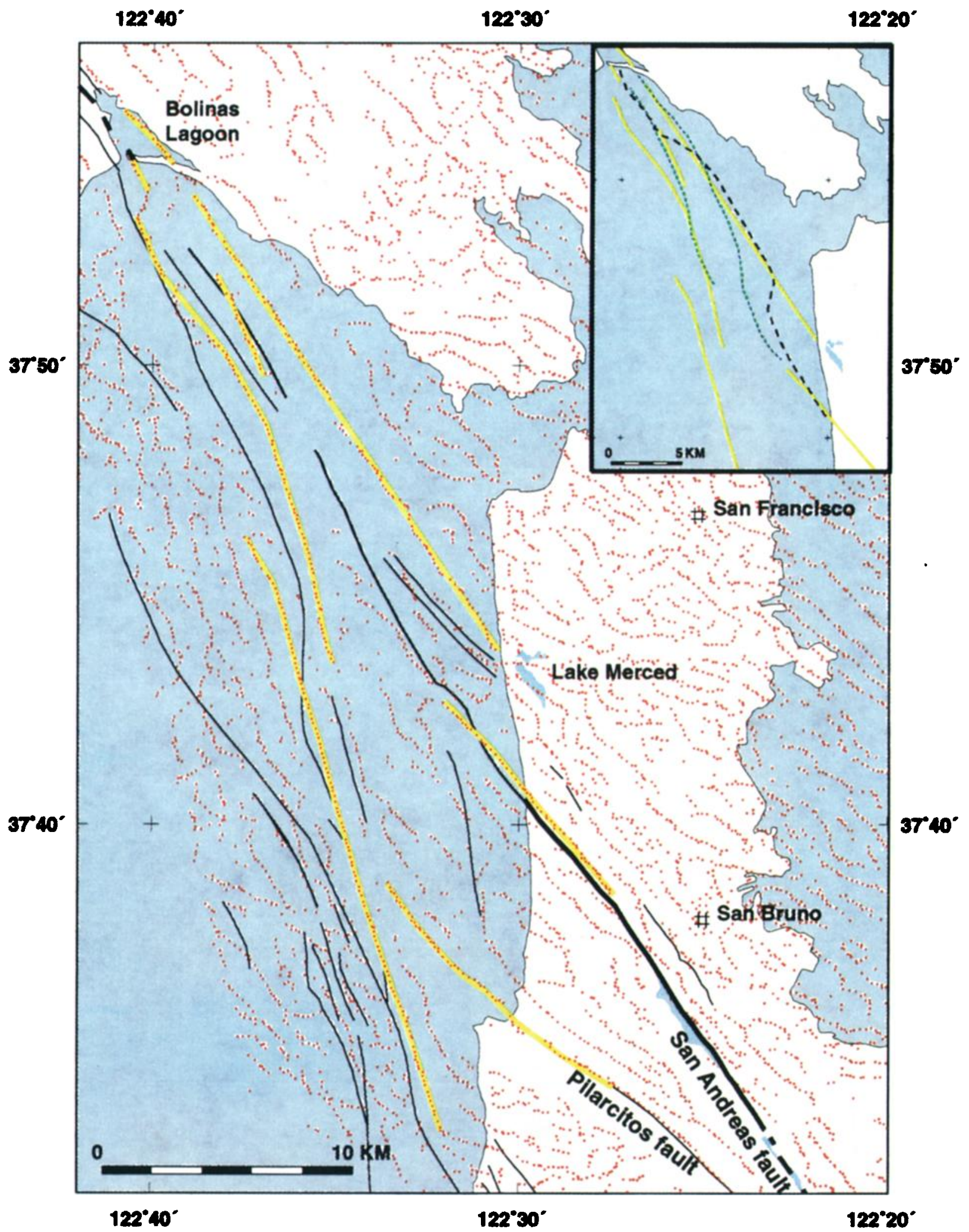

Plate 2. Maximum horizontal gradient locations (red pluses) from Plate 1 and inferred offshore fault structure (heavy yellow lines). Thin black lines are the currently mapped offshore Quaternary faulting from Bortugno et al. [1992]; the 1906 rupture on the San Andreas fault is in bold black. The inset compares new fault interpretation with Cooper's [1973] "recent trace of the San Andreas fault" (heavy black dashed line) and young "San Andreas" graben (thin green dashed line), both inferred from high-resolution seismic profiling. 


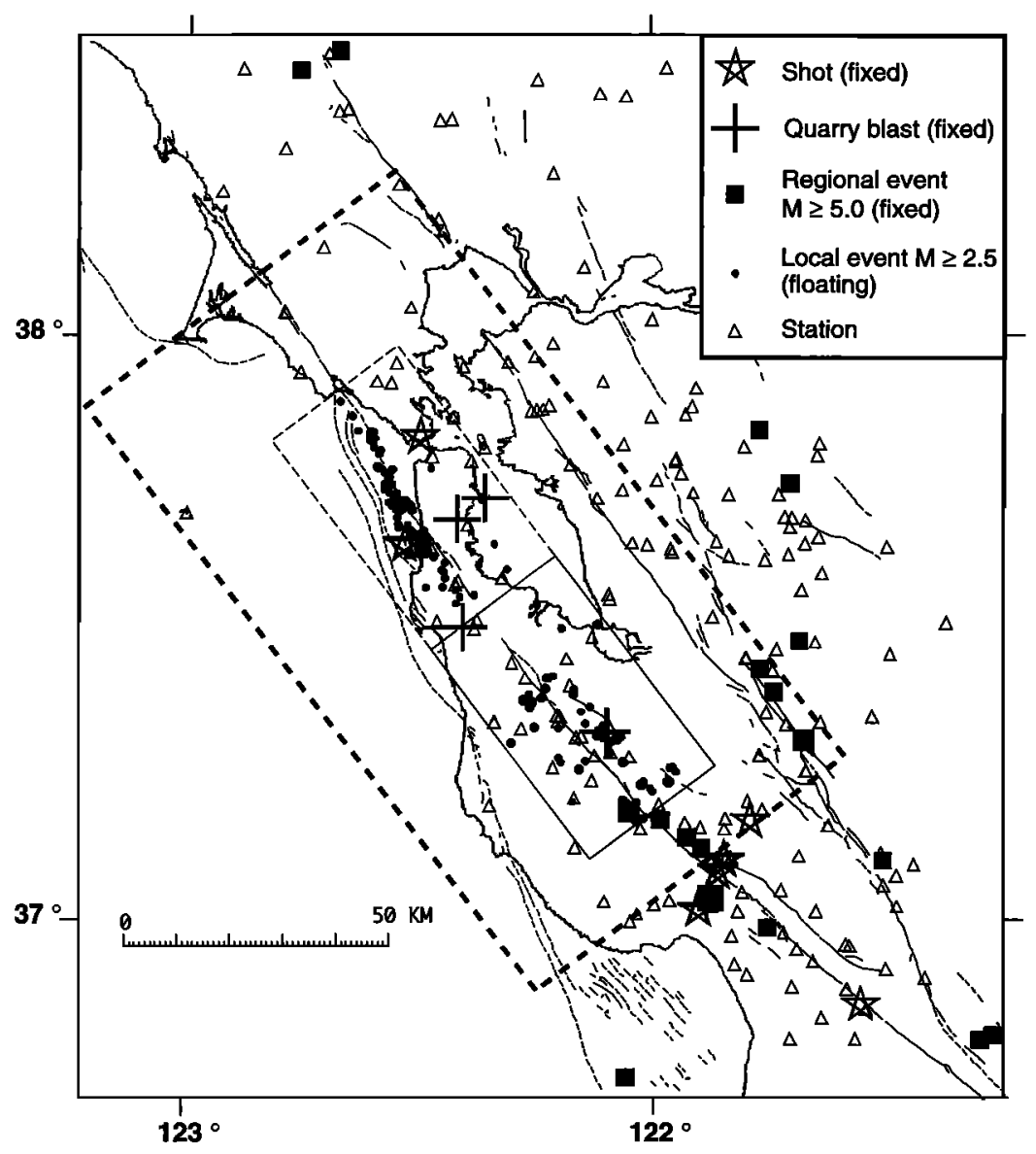

Figure 2. Map of calibration explosions, quarry blasts, earthquakes, and stations used in the velocity inversion. Inner rectangles mark northern (dashed) and southern (solid) study areas in which earthquakes were relocated. The outer bold, dashed rectangle defines area additional area where station corrections were redetermined in order to better constrain focal mechanisms.

with fixed hypocenters. The regional earthquakes were included to better resolve the refractor velocities, especially $P n$. For the regional events we excluded arrivals within $20 \mathrm{~km}$ because we wanted the local events to provide the data for determining the shallower velocity structure.

Figure 3 shows the final velocity model (VELEST) in comparison with several velocity models for the San Francisco Bay region. Velocity layer boundaries in the inversion were set at $3-\mathrm{km}$ intervals (except in the uppermost $2 \mathrm{~km}$ ). The resulting best fit velocity structure is generally slower than the starting refraction-derived Peninsula model of Catchings and Kohler [1996]. However, it represents an average of Catchings and Kohler's [1996] model and two other velocity models determined in the peninsula area: one from a profile along the axis of San Francisco Bay and the other from a profile running out the Golden Gate, both from Holbrook et al. [1996]. We ran tests involving 1-km variations in the Moho depth utilizing the regional ( $M \geq 5.0$ events) and found that an average Moho depth of $\sim 22-24 \mathrm{~km}$ best fit the regional earthquake travel times. The adopted average Moho depth of $\sim 23.5 \mathrm{~km}$ in the final velocity model is not well constrained by these tests. However, the Moho is probably deeper than the 21-km depth determined in Catchings and Kohler's [1996] refraction survey aligned along the San Andreas fault. Our Moho velocity of 8.0 $\mathrm{km} \mathrm{s}^{-1}$ is identical to the refraction-determined Moho velocity in that survey.

The second step in the inversion procedure was to determine individual station delays. These time adjustments help correct for variations in near-surface site conditions as well as for geologic complexity resulting in departures from the assumed $1-D$ velocity model. Because of differences in tectonism and geomorphology that could be reflected in azimuthally variable seismic velocities, station delays were computed separately for events occurring in the northern (dashed) and southern (solid) subareas (inner rectangles in Figure 2). Station delays were also computed for stations within the larger, outer rectangle shown in Figure 2 so that we could utilize first motion data from these stations to calculate fault plane solutions.

Determining station corrections for the southern area was straightforward because of the dense station spacing. Fixed sources in the southern area include quarry blasts with known locations as well as six chemical shots from Catchings and Kohler's [1996] active seismic experiment. To obtain station delays for the northern subarea, we used three fixed sources: Uhrhammer's [1981] relocation of a $M_{L}=4.41979$ San Andreas earthquake, a controlled offshore detonation in 1992 of a World War II marine mine by the Navy $\left(37.6440^{\circ} \mathrm{N}\right.$, $122.5312^{\circ} \mathrm{W}$ ), and one of Catchings and Kohler's refraction 


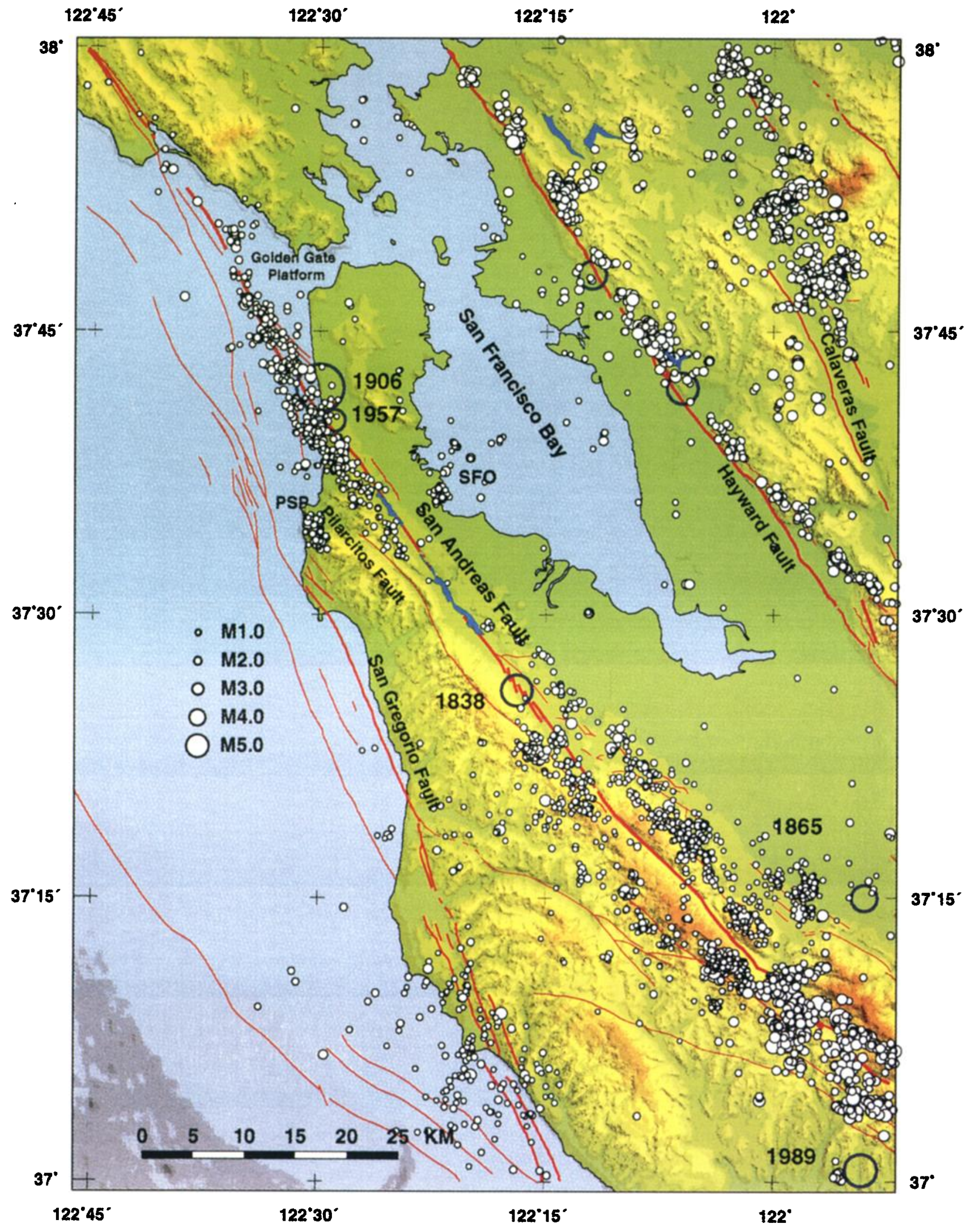

$\begin{array}{llllllllllll}-200 & -100 & 0 & 100 & 200 & 300 & 400 & 500 & 600 & 700 & 800 & \text { meters }\end{array}$

Plate 3. Relocated seismicity $\left(M_{d} \geq 1.5\right)$ for San Francisco Peninsula together with relocated seismicity $\left(M_{d} \geq 1.5\right)$ in the San Francisco bay block [Olson and Zoback, 1998], and NCSN locations of $M_{d} \geq 2.0$ events in the East Bay and Loma Prieta aftershock region. Seismicity is for the time period 1969-1995. 


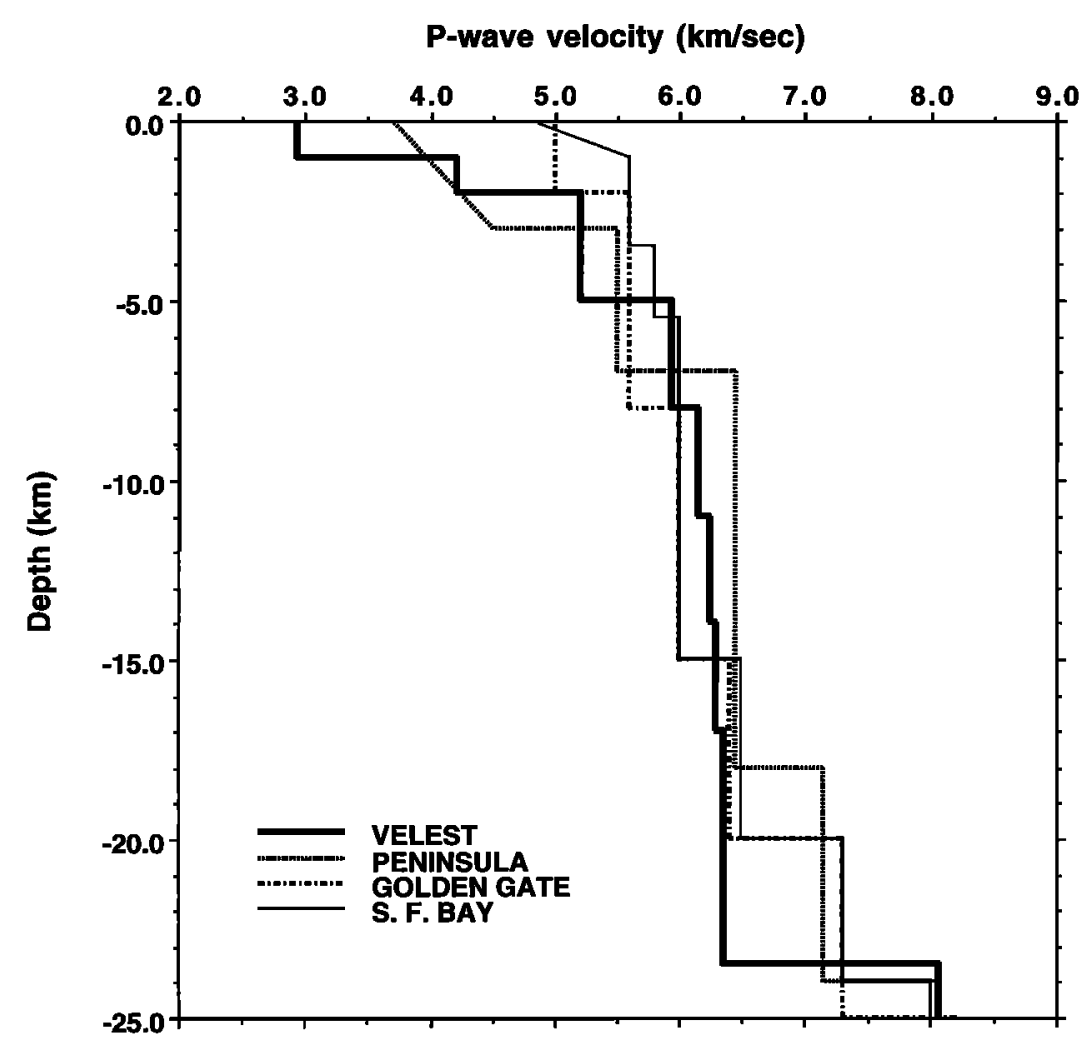

Figure 3. Velocity-depth model determined from the VELEST inversion compared to velocity depth determinations from active seismic experiments in the Bay area: Peninsula profile [Catchings and Kohler, 1996]; Golden Gate profile [Holbrook et al., 1996]; and San Francisco Bay profile [Holbrook et al., 1996].

shots beneath the Golden Gate. Station corrections determined for the two areas correlate well with surface geology. The average station delay for stations on bedrock is $+0.02 \mathrm{~s}$, whereas the average delay on stations on Tertiary sedimentary rocks was $-0.14 \mathrm{~s}$.

Once the new station corrections were computed, we relocated the NCSN hypocenters in the study area using the standard NCSN location program, HYPOINVERSE [Klein, 1989]. The relocation procedure resulted in a slight reduction in the overall mean root-mean-square (RMS) travel time residual for the data set (from $0.09 \pm 0.05$ to $0.08 \pm 0.03 \mathrm{~s}$ ). The relocation resulted in a reduction in standard location errors, as indicated by the standard estimate of the horizontal (ERH) and depth (ERZ) errors for each event calculated by HYPOINVERSE. There was a $25 \%$ reduction in ERH and a $30 \%$ reduction in ERZ as well as a $50 \%$ and $64 \%$ reduction, respectively, in their standard deviations (ERH, $0.46 \pm 0.33 \mathrm{~km}$ from $0.57 \pm 0.66$ $\mathrm{km}$; ERZ, $0.77 \pm 0.52 \mathrm{~km}$ from $1.11 \pm 1.45 \mathrm{~km}$ ). Note that these standard error parameters underestimate absolute errors; both ERH and ERZ are about 0.42 times smaller than the principal axes of the $95 \%$ confidence ellipsoid for each hypocenter. A more reliable measure of the true errors of the hypocentral locations comes from relocation of known quarry blasts and refraction shots within the study area. Comparing our locations with the actual locations, we found horizontal errors that ranged from 0.06 to $2.50 \mathrm{~km}$, with a mean of $0.85 \pm$ $0.47 \mathrm{~km}$. The vertical errors ranged between 0.20 and $3.10 \mathrm{~km}$, with a mean of $0.71 \pm 0.39 \mathrm{~km}$. For the purposes of this study, we defined well-located events as those with $\mathrm{ERH}<2.0 \mathrm{~km}$, ERZ $<3.0 \mathrm{~km}$, and RMS $<0.20 \mathrm{~s}$, and recorded on $>7$ stations. Coda (duration) magnitudes $M_{d}$ were computed us- ing the empirically derived equation of Eaton [1992], which closely approximates $M_{L}$ for $M_{d}<3.8$ events.

Resolution in the northern subarea is much poorer because of only one offshore station and potential complications related, at least locally, to a large velocity contrast across the San Andreas fault. Uhrhammer [1981] did a careful study of the location and focal mechanism solution for one of the largest events in the northern area since 1957, the 4.4 event on the coast south of San Francisco in 1979. His map of first-motion polarities indicates that the earthquake is a right-lateral strikeslip event probably occurring on the San Andreas. However, many of the distant $(>45 \mathrm{~km})$ first arrivals show a distinct lateral refraction of $34^{\circ}$ (implying a velocity contrast of $19 \%$, with the higher velocity on the NE side of the fault). These refracted arrivals added noise to the focal mechanism while not obscuring it. Uhrhammer used these observations to relocate the 1979 event to lie almost directly on the San Andreas fault, a 3.5-km shift to the NE from his preliminary epicentral location. Our relocation of the 1979 event places it $600 \mathrm{~m} \mathrm{SW}$ of the San Andreas fault and Uhrhammer's location. Hence it is likely that much of the relocated seismicity distribution in the northern zone may be shifted $\sim 600 \mathrm{~m} \mathrm{SW}$ from its actual location.

\section{Hypocentral Distribution and Focal Mechanisms of Relocated Seismicity}

An epicentral map of well-located earthquakes using the selection criteria detailed above and locations based on the new 1-D velocity model and separate station corrections for the northern and southern subareas is shown in Plate 3 . The 
Table 1. Focal Mechanism Parameters for Northern Area

\begin{tabular}{|c|c|c|c|c|c|c|c|c|c|c|c|c|c|c|c|}
\hline \multirow[b]{2}{*}{ No. } & \multirow[b]{2}{*}{ Date } & \multirow[b]{2}{*}{ Time, UT } & \multirow{2}{*}{$\begin{array}{l}\text { Lati- } \\
\text { tude, } \\
\mathrm{N}\end{array}$} & \multirow{2}{*}{$\begin{array}{l}\text { Longi- } \\
\text { tude, } \\
\text { W }\end{array}$} & \multirow[b]{2}{*}{$\begin{array}{c}\text { Depth, } \\
\text { km }\end{array}$} & \multirow{2}{*}{$\begin{array}{c}\text { Dura- } \\
\text { tion } \\
\text { Magni- } \\
\text { tude }\end{array}$} & \multirow{2}{*}{$\begin{array}{l}\text { Number } \\
\text { of First } \\
\text { Motions }\end{array}$} & \multicolumn{2}{|c|}{ Plane 1} & \multicolumn{2}{|c|}{ Plane 2} & \multicolumn{2}{|c|}{$P$ Axis } & \multicolumn{2}{|c|}{$T$ Axis } \\
\hline & & & & & & & & Strike & Dip & Strike & Dip & $\begin{array}{l}\text { Azi- } \\
\text { muth }\end{array}$ & Plunge & $\begin{array}{l}\text { Azi- } \\
\text { muth }\end{array}$ & Plunge \\
\hline 1a & March 31, 1971 & $1703: 36.21$ & $37^{\circ} 40.81^{\prime}$ & $122^{\circ} 30.57^{\prime}$ & 9.23 & 3.20 & 18 & 160 & 15 & 309 & 77 & 209 & 57 & 45 & 32 \\
\hline $1 b$ & March 31, 1971 & $1703: 36.21$ & $37^{\circ} 40.81^{\prime}$ & $122^{\circ} 30.57^{\prime}$ & 9.23 & 3.20 & 18 & 345 & 45 & 192 & 48 & 172 & 76 & 269 & 2 \\
\hline 2 & July 25,1971 & 0913:28.86 & $37^{\circ} 42.60^{\prime}$ & $122^{\circ} 30.64^{\prime}$ & 7.46 & 3.40 & 32 & 150 & 70 & 38 & 44 & 17 & 49 & 268 & $1 \overline{5}$ \\
\hline $3 \mathrm{a}$ & Nov. 1, 1977 & $0406: 43.23$ & $37^{\circ} 42.58^{\prime}$ & $122^{\circ} 32.38^{\prime}$ & 6.50 & 3.10 & 23 & 320 & 80 & 226 & 70 & 185 & 21 & 92 & 7 \\
\hline $3 b$ & Nov. 1, 1977 & $0406: 43.23$ & $37^{\circ} 42.58^{\prime}$ & $122^{\circ} 32.38^{\prime}$ & 6.50 & 3.10 & 23 & 40 & 45 & 144 & 76 & 14 & 42 & 265 & 19 \\
\hline 4 & April 28, 1979 & $0044: 44.61$ & $37^{\circ} 38.72^{\prime}$ & $122^{\circ} 28.02^{\prime}$ & 12.90 & 4.40 & 38 & 60 & 85 & 152 & 70 & 14 & 18 & 108 & 10 \\
\hline 5 & March 9, 1986 & 0128:12.62 & $37^{\circ} 40.01^{\prime}$ & $122^{\circ} 29.92^{\prime}$ & 4.61 & 3.00 & 28 & 335 & 85 & 239 & 40 & 210 & 37 & 96 & 29 \\
\hline $6 a$ & Nov. 2, 1986 & $0346: 14.27$ & $37^{\circ} 38.08^{\prime}$ & $122^{\circ} 29.08^{\prime}$ & 7.55 & 3.00 & 32 & 45 & 90 & 135 & 80 & 360 & 7 & 90 & 7 \\
\hline $6 b$ & Nov. 2, 1986 & $0346: 14.27$ & $37^{\circ} 38.08^{\prime}$ & $122^{\circ} 29.08^{\prime}$ & 7.55 & 3.00 & 32 & 320 & 90 & 230 & 30 & 203 & 38 & 77 & 38 \\
\hline $7 \mathrm{a}$ & Feb. 1, 1987 & $1753: 18.76$ & $37^{\circ} 42.97^{\prime}$ & $122^{\circ} 31.16^{\prime}$ & 4.69 & 3.40 & 40 & 335 & 85 & 66 & 80 & 21 & 3 & 290 & 11 \\
\hline $7 \mathrm{~b}$ & Feb. 1, 1987 & $1753: 18.76$ & $37^{\circ} 42.97^{\prime}$ & $122^{\circ} 31.16^{\prime}$ & 4.69 & 3.40 & 40 & 20 & 40 & 187 & 51 & 53 & 82 & 283 & 5 \\
\hline 8 & Sept. 19, 1987 & 1833:59.07 & $37^{\circ} 46.66^{\prime}$ & $122^{\circ} 34.94^{\prime}$ & 10.58 & 3.30 & 30 & 55 & 55 & 190 & 45 & 22 & 65 & 124 & 6 \\
\hline 9 & Dec. 30, 1987 & 0109:10.58 & $37^{\circ} 46.72^{\prime}$ & $122^{\circ} 34.82^{\prime}$ & 10.32 & 3.20 & 49 & 20 & 45 & 161 & 52 & 9 & 69 & 269 & 4 \\
\hline 10 & Feb. 12, 1989 & 1949:05.49 & $37^{\circ} 49.66^{\prime}$ & $122^{\circ} 36.26^{\prime}$ & 4.84 & 3.10 & 42 & 25 & 25 & 152 & 74 & 37 & 56 & 258 & 27 \\
\hline 11 & Feb. 12,1989 & $1949: 49.92$ & $37^{\circ} 49.66^{\prime}$ & $122^{\circ} 35.84^{\prime}$ & 1.78 & 2.90 & 24 & 20 & 45 & 173 & 48 & 13 & 76 & 276 & 2 \\
\hline 12 & Feb. 13, 1989 & 0600:28.16 & $37^{\circ} 50.05^{\prime}$ & $122^{\circ} 36.35^{\prime}$ & 4.39 & 3.00 & 31 & 25 & 70 & 178 & 22 & 311 & 64 & 107 & 24 \\
\hline 13 & Feb. 13, 1989 & 0801:41.58 & $37^{\circ} 50.16^{\prime}$ & $122^{\circ} 36.39^{\prime}$ & 4.22 & 3.60 & 39 & 60 & 85 & 163 & 21 & 351 & 46 & 132 & 37 \\
\hline 14 & Nov. 6, 1989 & $2337: 24.26$ & $37^{\circ} 38.96^{\prime}$ & $122^{\circ} 28.69^{\prime}$ & 4.14 & 3.10 & 48 & 120 & 65 & 10 & 54 & 340 & 45 & 243 & 6 \\
\hline 15 & Nov. 24, 1993 & 1518:08.14 & $37^{\circ} 46.43^{\prime}$ & $122^{\circ} 35.04^{\prime}$ & 10.49 & 3.00 & 36 & 35 & 50 & 162 & 54 & 12 & 60 & 278 & 2 \\
\hline 16 & Jan. 2, 1994 & 0311:18.24 & $37^{\circ} 46.35^{\prime}$ & $122^{\circ} 35.06^{\prime}$ & 10.91 & 3.00 & 41 & 25 & 35 & 159 & 64 & 30 & 63 & 267 & 16 \\
\hline 17 & Nov. 19, 1991 & 0207:00.28 & $37^{\circ} 34.64^{\prime}$ & $122^{\circ} 30.27^{\prime}$ & 7.99 & 2.40 & 35 & 65 & 75 & 332 & 80 & 19 & 4 & 288 & 18 \\
\hline 18 & Feb. 16, 1992 & $1823: 22.55$ & $37^{\circ} 34.89^{\prime}$ & $122^{\circ} 30.78^{\prime}$ & 7.84 & 2.40 & 43 & 70 & 75 & 335 & 71 & 202 & 3 & 293 & 25 \\
\hline 19 & March 25,1996 & $1117: 11.93$ & $37^{\circ} 34.65^{\prime}$ & $122^{\circ} 25.58^{\prime}$ & 7.58 & 2.70 & 60 & 10 & 65 & 149 & 32 & 314 & 64 & 85 & 18 \\
\hline 20 & July 1, 1996 & 0433:05.09 & $37^{\circ} 42.80^{\prime}$ & $122^{\circ} 32.76^{\prime}$ & 10.94 & 3.10 & 58 & 35 & 50 & 153 & 61 & 10 & 53 & 272 & 6 \\
\hline 21 & April 2, 1988 & 1043:00.40 & $37^{\circ} 36.51^{\prime}$ & $122^{\circ} 22.37^{\prime}$ & 10.84 & 2.30 & 102 & 0 & 65 & 250 & 54 & 220 & 45 & 123 & 6 \\
\hline 1957 & March 22, 1957 & $1944: 20.86$ & $37^{\circ} 40.27$ & $122^{\circ} 29.05^{\prime}$ & 7.27 & 5.30 & 31 & 315 & 46 & 91 & 53 & 301 & 66 & 202 & 4 \\
\hline
\end{tabular}

depth distribution of seismicity is shown in the cross sections in Plate 4, in which events that occurred before and after the 1989 Loma Prieta earthquake are depicted with different colors (location of section lines are given in Plates 5 and 6). Compared with the routine NCSN processing locations, the relocated events show the same overall pattern as observed in the standard processing, but seismicity is generally more tightly clustered. In the northern subarea the relocation resulted in a $0.5-$ to $1.0-\mathrm{km}$ shift in epicenters toward the NE; in the northern third of the southern subarea the relocated events shift $<500 \mathrm{~m}$ to the NE, while in the southern two thirds of the southern subarea the relocated events were shifted $0.5-1.0 \mathrm{~km}$ to the SW.

Focal mechanisms were computed for all $M_{d} \geq 3.0$ relocated events (and a few selected smaller events as discussed below) using only first motion picks from NCSN hand processing (as opposed to automated computer picks) and newly computed takeoff angles based on the revised seismic velocity structure. Mechanisms and 95\% confidence solutions were determined using FPFIT, a least squares, grid search procedure which minimizes the number of discrepant first motions [Reasenberg and Oppenheimer, 1985]. The focal mechanisms for the $M_{d} \geq 3.0$ earthquakes in the study area are plotted on Plates 5 and 6 for the northern and southern subareas, respectively. Each solution is numbered and the focal mechanism parameters are tabulated in Tables 1 and 2, and equal area projections showing first motions are given in Figures 4 and 5. In some cases two possible, distinct focal mechanisms statistically fit the data equally well for a given event (no overlap in 95\% confidence interval of $P$ and $T$ axes). Both mechanisms and their fit to first motions are shown in Figures 4 and 5 , although only one solution is plotted in Plates 5 and 6 (the solution with the smallest standard error).
Both the seismicity and focal mechanism data suggest two discrete and distinct zones of deformation at the northern and southern ends of the 100-km San Francisco peninsula section of the San Andreas fault examined. These zones are separated on the central peninsula by a $\sim 15-\mathrm{km}$-long zone of seismic quiescence and are discussed individually below.

\subsection{Northernmost Peninsula and Golden Gate Platform}

Epicenters in the northern zone of seismicity occur in a 3- to $5-\mathrm{km}$-wide zone west of the mapped San Andreas fault onshore and its newly defined location and geometry offshore. In cross-sectional view (Plate 4a) the breadth of the seismic zone and its apparent westward offset from the San Andreas fault can be seen to persist throughout the entire seismogenic crust, from 3-km to about 13-km depth. Perhaps $\sim 600 \mathrm{~m}$ of offset of seismicity SW from the San Andreas fault may be attributed to systematic location errors related to the large velocity contrast across the San Andreas fault described above. However, since the focal mechanism data indicate that this seismicity is the result of both normal and right-lateral strike-slip faulting on $\mathrm{N}$ to NW trending planes (Figure 4 and Plate 5), many of the earthquakes in this northern zone of deformation may actually be occurring on distinct normal faults within the Pilarcitos block, rather than on the bounding strike-slip faults.

Because of limited first motions and azimuthal coverage, particularly for the offshore and older events, some of the focal mechanisms in this northern area are poorly constrained (particularly $1,3,8$, and 13). Several events have first motions yielding both a normal and strike-slip mechanism that fit the data to within a $90 \%$ confidence limit (events 3,6, and 7) although the strike-slip mechanism in two of the cases ( 3 and 7) has slightly smaller errors. Several mechanisms (e.g., 9, 15, 16,19 , and 20 ) have compressional arrivals spanning a $120^{\circ}-$ 


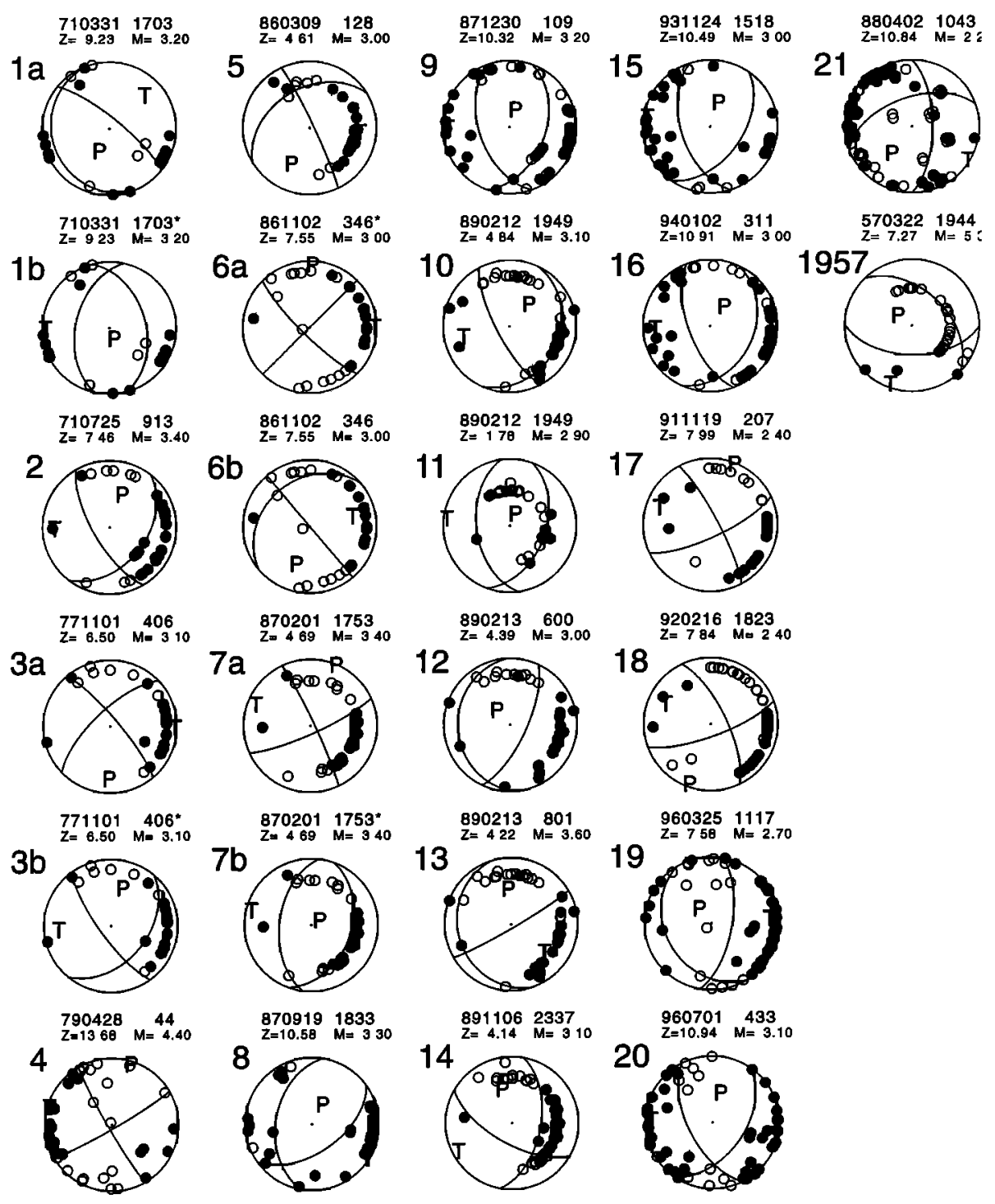

Figure 4. Lower hemisphere equal area projections of focal mechanisms with first motion data for the northern area; location of events is given in Plate 5. Dilational first motions are shown by solid circles, compressional first motions are given by open circles. An a or b after the focal mechanism number indicates that it is one of two possible solutions. Captions above each event give date (year month day), time (hour minute), depth ( $Z$, in kilometers), and duration magnitude.

$150^{\circ}$ range in azimuth, clearly establishing that the normal faulting is real and not just an artifact of the poor station coverage in this area. Mechanism 19 is for a recent $M_{d}=2.7$ event; it is included because it is very well constrained and is the only mechanism in the southernmost $10 \mathrm{~km}$ of seismicity in the northern zone of seismicity.

It is difficult to establish whether the normal- and strikeslip-faulting events in the northern deformation zone have distinct spatial-depth distributions. Both strike-slip and normal events occur in close proximity and similar depth ranges within and directly to the southeast of the San Andreas stepover region (Plate 5). Northeast of the stepover the mechanisms all show normal faulting $(8-13,15$, and 16$)$, with the best constrained normal faulting mechanisms $(8,9,15$, and 16) all located at depths of $10-11 \mathrm{~km}$ opposite the Golden Gate. Although not shown, focal mechanisms were computed for all events down to $M_{d}=1.5$ (limit of reasonable focal sphere coverage). Significantly, no thrust mechanisms were identified anywhere in the northern section, even in the vicinity of a mapped late Quaternary thrust, the Serra fault, on the NE side of the San Andreas fault (Figure 1 and Plate 5).

The close spatial proximity of strike-slip and normal faulting also exists for larger-magnitude events. The largest earthquake during the period of relatively dense instrumentation (post1968 ) is a $M_{d}=4.4$ right-lateral strike-slip event located on the San Andreas fault at a depth of $12.9 \pm 1.0 \mathrm{~km}$ near Daly City in 1979 (event 4 in Plate 5). As was noted previously, the first motion distribution pattern for this event indicated refracted first motions due to velocity contrasts across the San Andreas. Excluding the obvious refracted first motions, Uhrhammer [1981] obtained the well-constrained $\left(< \pm 5^{\circ}\right.$ uncertainty in nodal plane attitude) strike-slip solution with the 
Table 2. Focal Mechanism Parameters for Southern Area

\begin{tabular}{|c|c|c|c|c|c|c|c|c|c|c|c|c|c|c|c|}
\hline \multirow[b]{2}{*}{ No. } & \multirow[b]{2}{*}{ Date } & \multirow[b]{2}{*}{ Time } & \multirow{2}{*}{$\begin{array}{l}\text { Lati- } \\
\text { tude, } \\
\mathbf{N}\end{array}$} & \multirow{2}{*}{$\begin{array}{l}\text { Longi- } \\
\text { tude, } \\
\text { W }\end{array}$} & \multirow[b]{2}{*}{$\begin{array}{c}\text { Depth, } \\
\text { km }\end{array}$} & \multirow{2}{*}{$\begin{array}{l}\text { Dura- } \\
\text { tion } \\
\text { Magni- } \\
\text { tude }\end{array}$} & \multirow{2}{*}{$\begin{array}{l}\text { Number } \\
\text { of First } \\
\text { Motions }\end{array}$} & \multicolumn{2}{|c|}{ Plane 1} & \multicolumn{2}{|c|}{ Plane 2} & \multicolumn{2}{|c|}{$P$ Axis } & \multicolumn{2}{|c|}{$T$ Axis } \\
\hline & & & & & & & & Strike & Dip & Strike & Dip & $\begin{array}{l}\text { Azi- } \\
\text { muth }\end{array}$ & Plunge & $\begin{array}{l}\text { Azi- } \\
\text { muth }\end{array}$ & Plunge \\
\hline 1 & Jan. 3, 1970 & 0251:58.20 & $37^{\circ} 18.87^{\prime}$ & $122^{\circ} 4.74^{\prime}$ & 6.42 & 3.70 & 26 & 120 & 40 & 313 & 51 & 37 & 5 & 267 & 82 \\
\hline 2 & Sept. 23, 1970 & 0451:27.84 & $37^{\circ} 24.27^{\prime}$ & $122^{\circ} 13.29^{\prime}$ & 7.24 & 3.50 & 25 & 150 & 25 & 319 & 65 & 52 & 20 & 220 & 69 \\
\hline 3 & March 23, 1992 & 0345:29.35 & $37^{\circ} 23.42^{\prime}$ & $122^{\circ} 13.96^{\prime}$ & 9.71 & 3.20 & 38 & 45 & 70 & 138 & 81 & 3 & 21 & 270 & 7 \\
\hline $4 a$ & Sept. 26, 1973 & $0404: 46.66$ & $37^{\circ} 18.62^{\prime}$ & $122^{\circ} 17.98^{\prime}$ & 7.11 & 3.20 & 24 & 135 & 70 & 315 & 20 & 225 & 25 & 45 & 65 \\
\hline $4 b$ & Sept. 26, 1973 & $0404: 46.66$ & $37^{\circ} 18.62^{\prime}$ & $122^{\circ} 17.98^{\prime}$ & 7.11 & 3.20 & 24 & 190 & 85 & 289 & 30 & 255 & 33 & 129 & 42 \\
\hline 5 & Nov. 12,1973 & $1817: 13.48$ & $37^{\circ} 14.25^{\prime}$ & $121^{\circ} 58.22^{\prime}$ & 12.40 & 4.50 & 57 & 215 & 85 & 309 & 50 & 164 & 31 & 269 & 23 \\
\hline 6 & March 12, 1974 & $1245: 28.47$ & $37^{\circ} 20.18^{\prime}$ & $122^{\circ} 15.01^{\prime}$ & 10.55 & 3.60 & 39 & 165 & 55 & 300 & 45 & 234 & 6 & 132 & 65 \\
\hline 7 & March 24, 1974 & 0137:15.39 & $37^{\circ} 8.91^{\prime}$ & $122^{\circ} 17.83^{\prime}$ & 14.54 & 3.10 & 34 & 345 & 75 & 250 & 71 & 208 & 25 & 117 & 3 \\
\hline 8 & June 19,1975 & $1617: 53.80$ & $37^{\circ} 22.72^{\prime}$ & $122^{\circ} 15.66^{\prime}$ & 9.88 & 3.40 & 39 & 105 & 60 & 304 & 31 & 202 & 14 & 350 & 73 \\
\hline 9 & June 20,1975 & 0534:00.89 & $37^{\circ} 22.61^{\prime}$ & $122^{\circ} 15.33^{\prime}$ & 9.55 & 3.30 & 36 & 100 & 55 & 325 & 45 & 211 & 6 & 313 & 65 \\
\hline 10 & June 20,1975 & 0816:18.10 & $37^{\circ} 22.32^{\prime}$ & $122^{\circ} 15.41^{\prime}$ & 10.55 & 3.40 & 40 & 305 & 70 & 193 & 44 & 63 & 15 & 172 & 49 \\
\hline $11 a$ & June 22,1975 & 0012:35.44 & $37^{\circ} 22.39^{\prime}$ & $122^{\circ} 15.37^{\prime}$ & 10.27 & 3.50 & 27 & 200 & 85 & 101 & 30 & 81 & 42 & 315 & 33 \\
\hline $11 \mathrm{~b}$ & June 22,1975 & 0012:35.44 & $37^{\circ} 22.39^{\prime}$ & $122^{\circ} 15.37^{\prime}$ & 10.27 & 3.50 & 27 & 55 & 5 & 215 & 85 & 123 & 50 & 307 & 40 \\
\hline 12 & July 27, 1977 & $2151: 17.55$ & $37^{\circ} 19.92^{\prime}$ & $122^{\circ} 6.85^{\prime}$ & 4.97 & 3.50 & 93 & 120 & 50 & 270 & 44 & 196 & 3 & 95 & 74 \\
\hline 13 & Dec. 12,1981 & 1511:09.18 & $37^{\circ} 23.36^{\prime}$ & $122^{\circ} 15.64^{\prime}$ & 7.95 & 3.70 & 39 & 95 & 60 & 334 & 48 & 212 & 7 & 312 & 55 \\
\hline 14 & May 14,1986 & 0030:09.48 & $37^{\circ} 22.59^{\prime}$ & $122^{\circ} 15.12^{\prime}$ & 11.34 & 3.20 & 36 & 115 & 35 & 319 & 57 & 39 & 11 & 265 & 74 \\
\hline 15 & June 12,1987 & $0543: 28.90$ & $37^{\circ} 18.44^{\prime}$ & $121^{\circ} 52.32^{\prime}$ & 10.27 & 3.10 & 59 & 85 & 65 & 328 & 46 & 203 & 11 & 307 & 52 \\
\hline 16 & Nov. 14,1988 & $1921: 47.37$ & $37^{\circ} 22.78^{\prime}$ & $122^{\circ} 15.46^{\prime}$ & 9.75 & 3.60 & 58 & 125 & 50 & 290 & 41 & 208 & 5 & 88 & 81 \\
\hline 17 & Nov. 14,1988 & $1952: 58.26$ & $37^{\circ} 22.79^{\prime}$ & $122^{\circ} 15.63^{\prime}$ & 9.75 & 3.40 & 50 & 125 & 50 & 305 & 40 & 215 & 5 & 35 & 85 \\
\hline 18 & May 9, 1989 & $1855: 40.17$ & $37^{\circ} 23.50^{\prime}$ & $122^{\circ} 10.23^{\prime}$ & 4.61 & 3.00 & 65 & 175 & 50 & 302 & 54 & 58 & 2 & 152 & 60 \\
\hline $19 a$ & Oct. 18,1989 & 0041:23.82 & $37^{\circ} 11.13^{\prime}$ & $122^{\circ} 3.73^{\prime}$ & 15.44 & 5.10 & 23 & 350 & 75 & 257 & 80 & 213 & 18 & 304 & 4 \\
\hline $19 \mathrm{~b}$ & Oct. 18,1989 & $0041: 23.82$ & $37^{\circ} 11.13^{\prime}$ & $122^{\circ} 3.73^{\prime}$ & 15.44 & 5.10 & 23 & 150 & 40 & 317 & 51 & 53 & 5 & 183 & 82 \\
\hline 20 & Oct. 18,1989 & 0108:08.98 & $37^{\circ} 11.70^{\prime}$ & $122^{\circ} 2.88^{\prime}$ & 13.96 & 3.60 & 23 & 75 & 90 & 345 & 70 & 208 & 14 & 302 & 14 \\
\hline 21 & Oct. 18,1989 & 0418:16.12 & $37^{\circ} 10.66^{\prime}$ & $122^{\circ} 3.44^{\prime}$ & 13.97 & 3.10 & 29 & 165 & 75 & 260 & 71 & 213 & 3 & 122 & 25 \\
\hline 22 & Oct. 20, 1989 & 0812:53.94 & $37^{\circ} 11.08^{\prime}$ & $122^{\circ} 3.83^{\prime}$ & 14.71 & 4.00 & 84 & 170 & 75 & 265 & 71 & 218 & 3 & 127 & 25 \\
\hline 23 & Nov. 7, 1989 & $2342: 37.37$ & $37^{\circ} 13.94^{\prime}$ & $122^{\circ} 1.74^{\prime}$ & 9.22 & 4.20 & 99 & 135 & 45 & 288 & 48 & 31 & 2 & 128 & 76 \\
\hline 24 & Nov. 16, 1989 & $0459: 29.05$ & $37^{\circ} 11.35^{\prime}$ & $122^{\circ} 2.63^{\prime}$ & 11.58 & 3.20 & 56 & 145 & 55 & 269 & 51 & 208 & 2 & 114 & 58 \\
\hline 25 & Dec. 2, 1989 & $2002: 00.49$ & $37^{\circ} 14.04^{\prime}$ & $122^{\circ} 1.89^{\prime}$ & 9.08 & 3.90 & 76 & 130 & 40 & 285 & 53 & 26 & 7 & 143 & 76 \\
\hline 26 & Dec. 26,1989 & $2246: 41.68$ & $37^{\circ} 11.79^{\prime}$ & $122^{\circ} 3.20^{\prime}$ & 14.02 & 3.50 & 54 & 80 & 90 & 350 & 90 & 35 & 0 & 125 & 0 \\
\hline 27 & Dec. 27,1989 & $1610: 01.30$ & $37^{\circ} 11.70^{\prime}$ & $122^{\circ} 3.46^{\prime}$ & 14.74 & 3.50 & 65 & 85 & 85 & 355 & 90 & 40 & 4 & 310 & 4 \\
\hline 28 & Jan. 22, 1990 & $0601: 10.55$ & $37^{\circ} 19.57^{\prime}$ & $122^{\circ} 7.51^{\prime}$ & 5.78 & 3.00 & 67 & 90 & 10 & 270 & 80 & 360 & 35 & 180 & 55 \\
\hline 29 & Aug. 22, 1990 & $2124: 05.59$ & $37^{\circ} 12.49^{\prime}$ & $122^{\circ} 4.16^{\prime}$ & 12.23 & 3.60 & 70 & 160 & 45 & 290 & 57 & 43 & 7 & 146 & 62 \\
\hline 30 & Sept. 23, 1990 & $1335: 47.15$ & $37^{\circ} 22.87^{\prime}$ & $122^{\circ} 10.64^{\prime}$ & 7.17 & 3.20 & 74 & 265 & 80 & 357 & 80 & 221 & 14 & 131 & 0 \\
\hline $31 \mathrm{a}$ & Sept. 26, 1990 & 0253:55.49 & $37^{\circ} 22.97^{\prime}$ & $122^{\circ} 10.67^{\prime}$ & 7.03 & 3.50 & 63 & 140 & 55 & 288 & 40 & 216 & 8 & 101 & 72 \\
\hline $31 b$ & Sept. 26,1990 & 0253:55.49 & $37^{\circ} 22.97^{\prime}$ & $122^{\circ} 10.67^{\prime}$ & 7.03 & 3.50 & 63 & 85 & 40 & 322 & 66 & 29 & 14 & 276 & 56 \\
\hline 32 & April 16, 1991 & $0056: 59.36$ & $37^{\circ} 18.94^{\prime}$ & $122^{\circ} 6.74^{\prime}$ & 4.75 & 3.10 & 54 & 115 & 45 & 295 & 45 & 25 & 0 & 281 & 90 \\
\hline 33 & June 28, 1991 & 0926:50.02 & $37^{\circ} 5.62^{\prime}$ & $122^{\circ} 19.99^{\prime}$ & 13.80 & 3.60 & 70 & 145 & 40 & 325 & 50 & 55 & 5 & 235 & 85 \\
\hline 34 & Sept. 12, 1991 & $0810: 02.46$ & $37^{\circ} 11.16^{\prime}$ & $122^{\circ} 4.42^{\prime}$ & 11.10 & 3.10 & 40 & 125 & 55 & 288 & 36 & 208 & 9 & 69 & 77 \\
\hline
\end{tabular}

right-lateral plane striking within $2^{\circ}$ of the mapped surface trace of the San Andreas. However, first motions for the largest post-1906 earthquake along the San Andreas fault in northern California before Loma Prieta, the $M_{L}=5.31957$ Daly City earthquake (labeled 1957 in Figure 4 and Plate 5), are generally consistent with other normal faulting mechanisms in the northern section, notably event 14 (Figure 4). A San Andreas fault-style right-lateral strike-slip mechanism (with a $\mathrm{N} 30^{\circ}-35^{\circ} \mathrm{W}$ striking vertical plane) is excluded by the 1957 first motions (for example, compare the 1957 mechanism with mechanism 4 in Figure 9, and note particularly that first motions for local stations in the south (shallow takeoff angles) are the wrong polarity if the 1957 event was a strike-slip earthquake). Relative relocation of the 1957 earthquake using the 1979 earthquake as a master event places the 1957 event $\sim 600$ $m$ to the NE of the mapped trace of the San Andreas fault at a depth of about $6 \mathrm{~km}$ [Marsden et al., 1995].

Seismicity has occurred rather uniformly with time throughout this northern zone of seismicity, although clusters of 5-10 events within a few days or weeks are not uncommon, particularly in the offshore areas. There is no discernible difference in either the depth or spatial distribution of seismicity before and after the 1989 Loma Prieta earthquake. However, the overall level of microseismicity in this area did statistically increase over the background in the 20 months following the Loma Prieta earthquake [Reasenberg and Simpson, 1992].

Two notable clusters of seismic activity occur on the northern San Francisco Peninsula away from the San Andreas fault. One cluster occurs along the margin of San Francisco Bay in the vicinity of San Francisco airport (SFO), and the other occurs SW of the San Andreas fault on the Pacific Coast near Point San Pedro (Plate 3). Persistent microseismicity in the vicinity of SFO has occurred since the onset of good instrumental coverage of the San Francisco Bay area in the late 1960s [Olson and Zoback, 1998]. These events have $M_{d} \leq 2.2$, and the best locations indicate activity in primarily the depth range $9-11 \mathrm{~km}$. Mechanism 21 is a composite mechanism for six events $\left(M_{d}=1.5-2.2\right)$ over a 5-year period and indicates combined normal and strike-slip movement on planes striking approximately N-S and E-W. Olson and Zoback [1998] conclude that this activity appears to be part of ongoing low level deformation of the San Francisco Bay block and cannot be related to any specific surface faulting.

Seismicity in the Point San Pedro area occurs in a NNW trending cluster about $3.5 \mathrm{~km}$ long by $2.0 \mathrm{~km}$ wide. Fifty-seven $M_{d} \geq 1.0$ events have occurred here since 1969 , the largest 


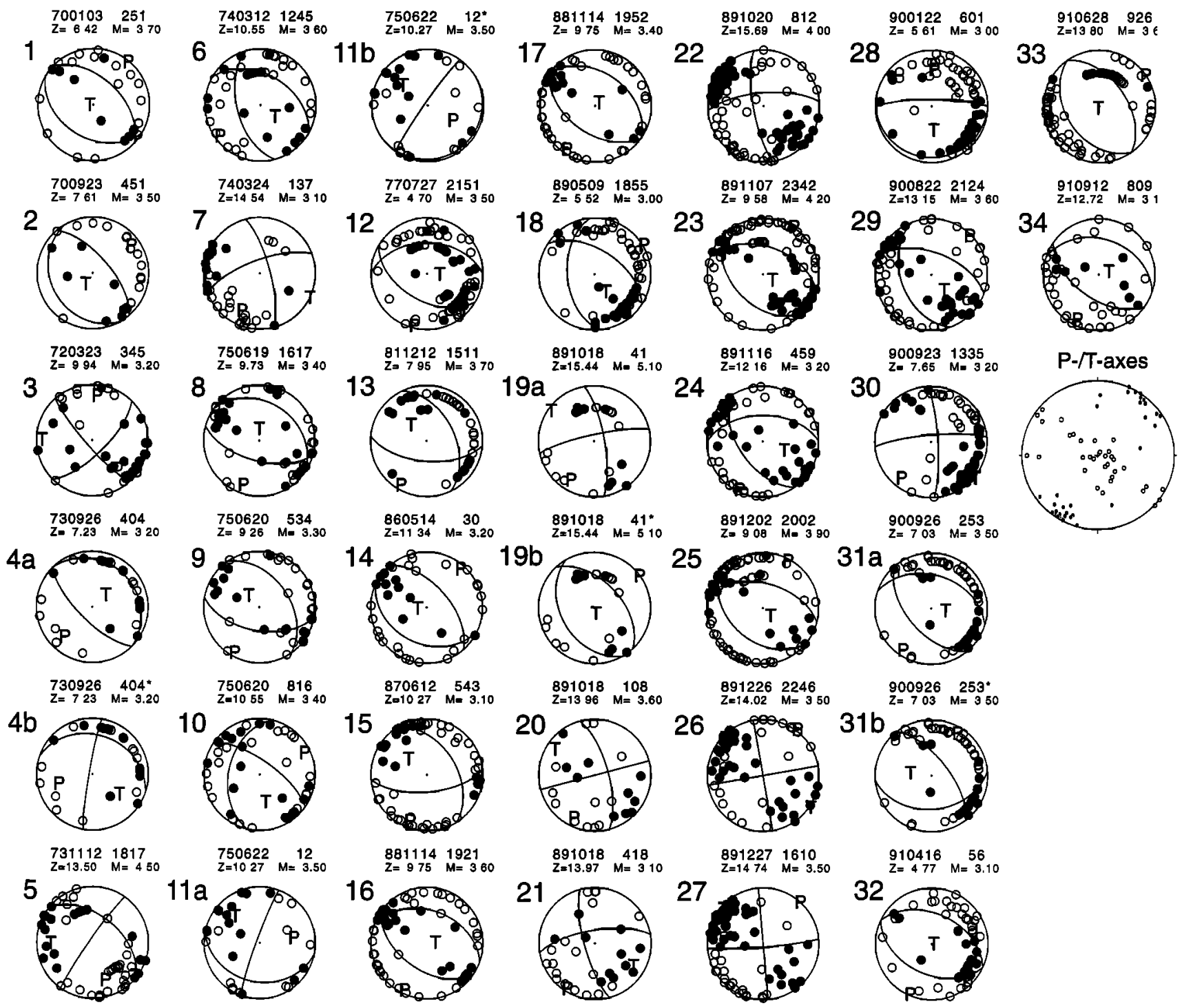

Figure 5. Lower hemisphere equal area projections of focal mechanisms with first motion data for the southern area; location of events given in Plate 6 . An a or b after the focal mechanism number indicates that it is one of two possible solutions. See Figure 4 for further explanation. Final lower hemisphere projection shows $P$ and $T$ axes (solid and open circles, respectively) for all mechanisms and demonstrates the predominance of NE (fault-normal) compression.

event being $M_{d}=2.5$, however most events are in the range $M_{d}=1.0-2.0$. This region exhibits swarm-like activity, with 49 of the 57 recorded events occuring in the 15 months between April 1991 and July 1992 and with 33 of those 49 events occurring in a 2 -week period in November 1991. Focal depths of the Point San Pedro events range between 6.0 and $8.0 \mathrm{~km}$. Focal mechanisms for the two largest events (17 and 18) indicate dominantly right-lateral strike-slip faulting on NNW trending plans. Hypocentral locations suggest these events are probably not related to the San Gregorio fault. Their locations $\sim 4 \mathrm{~km} \mathrm{NE}$ of the easternmost mapped strand of the San Gregorio fault zone and at depths of $8 \mathrm{~km}$ imply an average dip of about $63^{\circ} \mathrm{NE}$ for this fault, shallower than the $75^{\circ}-81^{\circ} \mathrm{NE}$ dips of the NNW trending nodal planes of events 17 and 18 . Alternately, this seismicity could be associated with the Pilarcitos fault; however, the $\mathrm{N} 55^{\circ} \mathrm{W}$ strike of that fault is signifi- cantly more westerly than the $\mathrm{N} 25^{\circ}-28^{\circ} \mathrm{W}$ strike of the nodal planes.

\subsection{Southern Peninsula}

On the southern San Francisco Peninsula, seismicity occurs in $7-$ to $10-\mathrm{km}$-wide bands on both sides of the San Andreas fault, beneath mapped subparallel Quaternary folds and thrusts within the Coast Ranges fault (Plates 3 and 4) [Page, 1982, 1992; Aydin and Page, 1984; Hitchcock et al., 1994]. Focal mechanisms indicate that this seismicity is due predominantly to thrust or reverse faulting on planes striking subparallel to the San Andreas fault (Plate 6). These mechanisms suggest a general pattern of fault-normal (NE) compression in the crustal zones adjacent to the fault (see stereoplot of the $P$ and $T$ axes shown in Figure 5) consistent with the surface geology. On cross sections S1, S2, and particularly S3 a vertical qui- 
a)

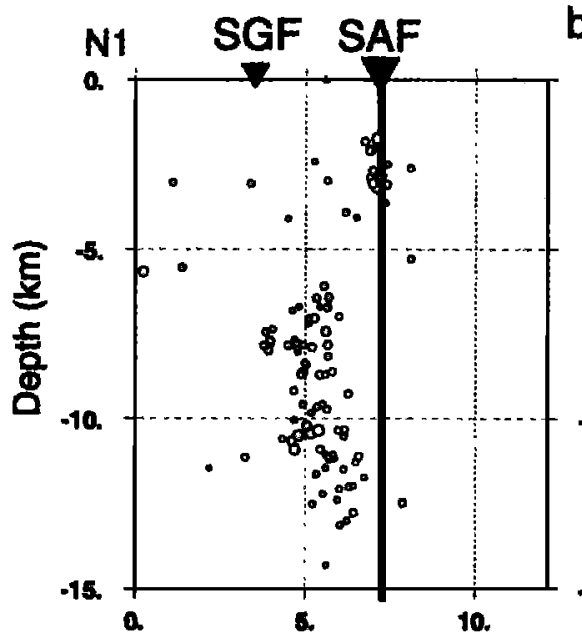

b)

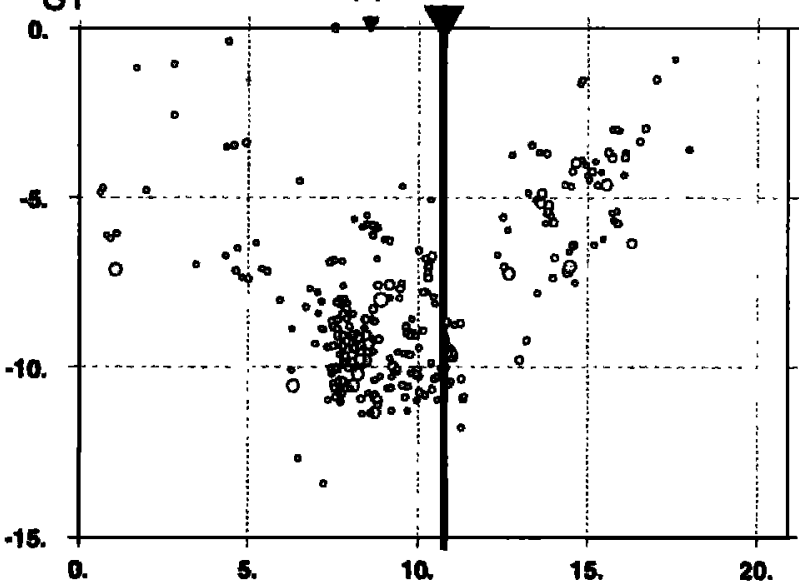

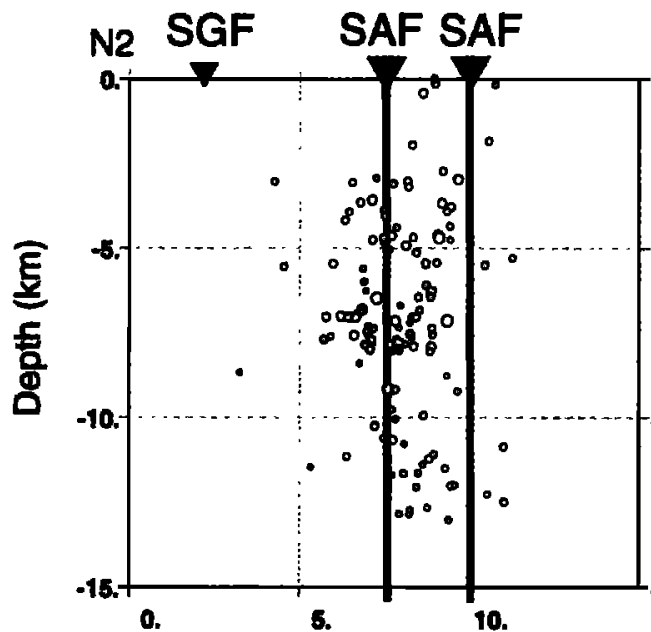
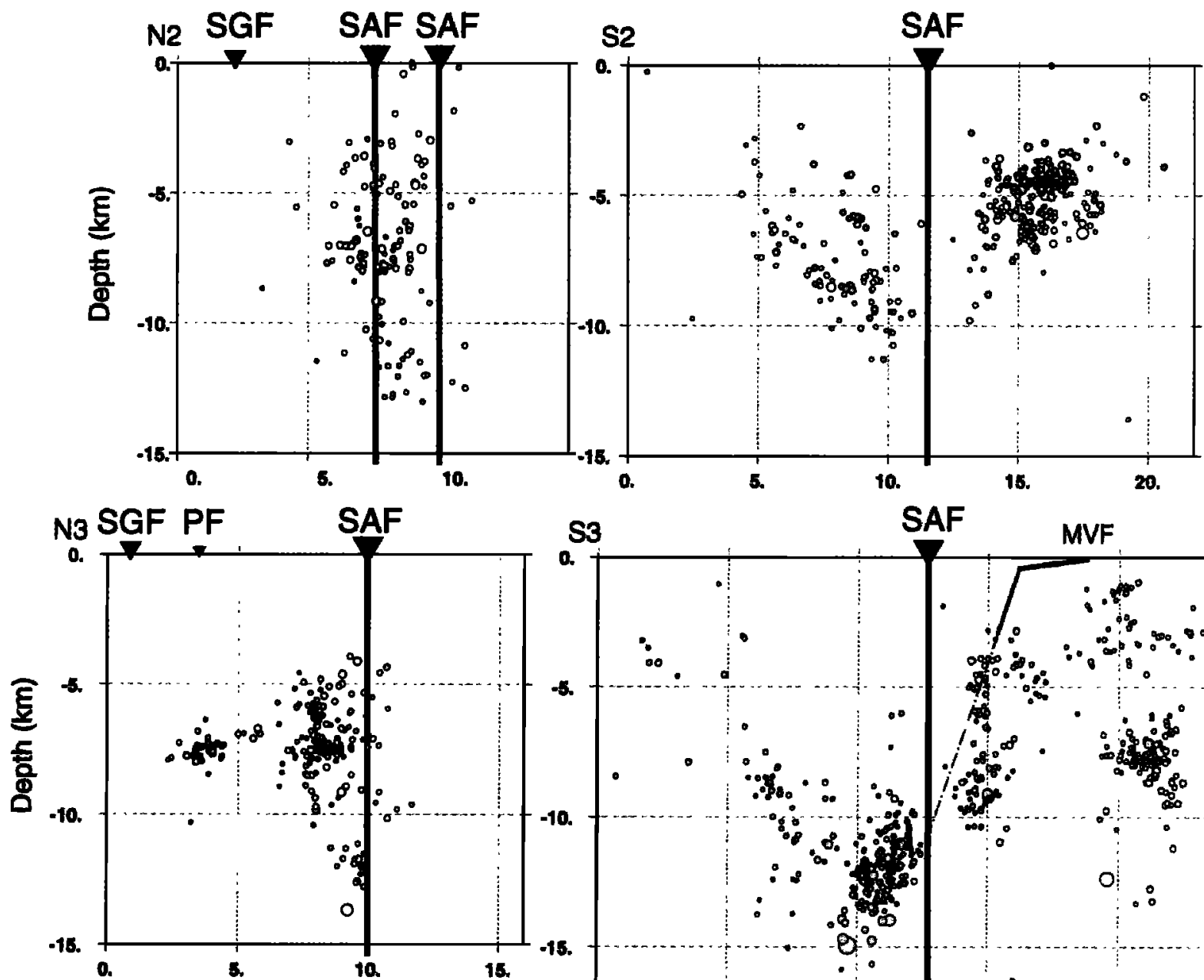

53

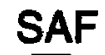

MVF

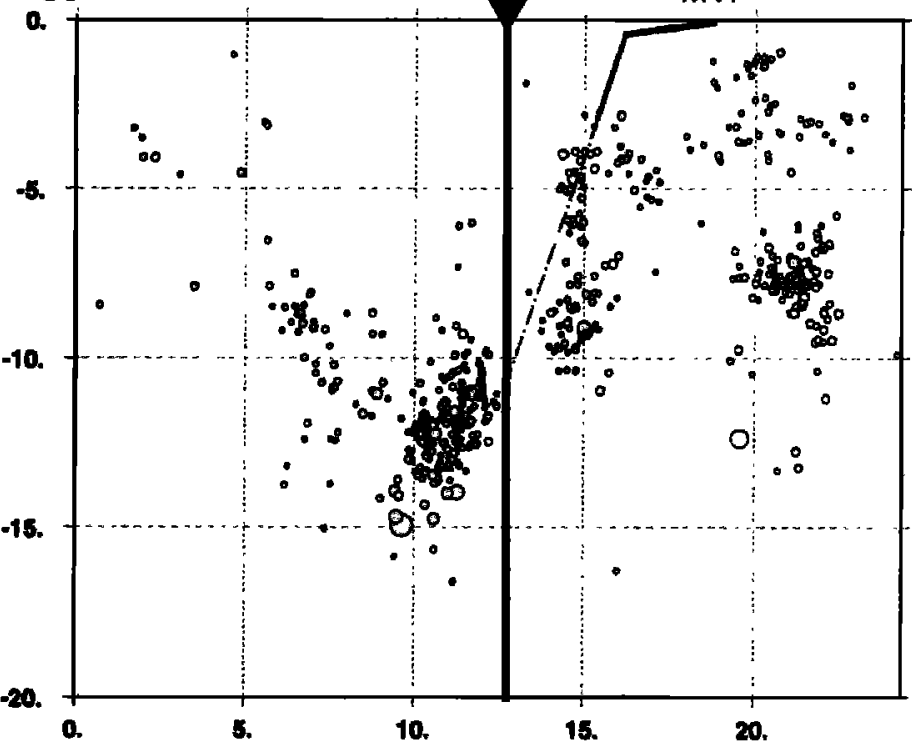

c. 5 .

10.

Plate 4. Cross sections of seismicity in the (a) northern and (b) southern zones of seismicity. Earthquakes occurring prior to the $1989 M=7.1$ Loma Prieta earthquake are shown by yellow circles; post-Loma Prieta events are shown in red. Symbol size is scaled to magnitude. Locations of cross-section profiles are given in Plates 5 and 6. Data were projected from $6 \mathrm{~km} \mathrm{NW}$ and SE of section lines. Triangles indicate surface location of faults: SAF, San Andreas fault; SGF, San Gregorio fault; and PF, Pilarcitos fault. Green line corresponds to location of a vertical San Andreas fault below surface trace. The blue line in section S3 gives subsurface geometry of the Monte Vista thrust fault (MVF) constrained to a depth of $\sim 3.0 \mathrm{~km}$ (solid line) by well data and gravity modeling [Langenheim et al., 1997]. 


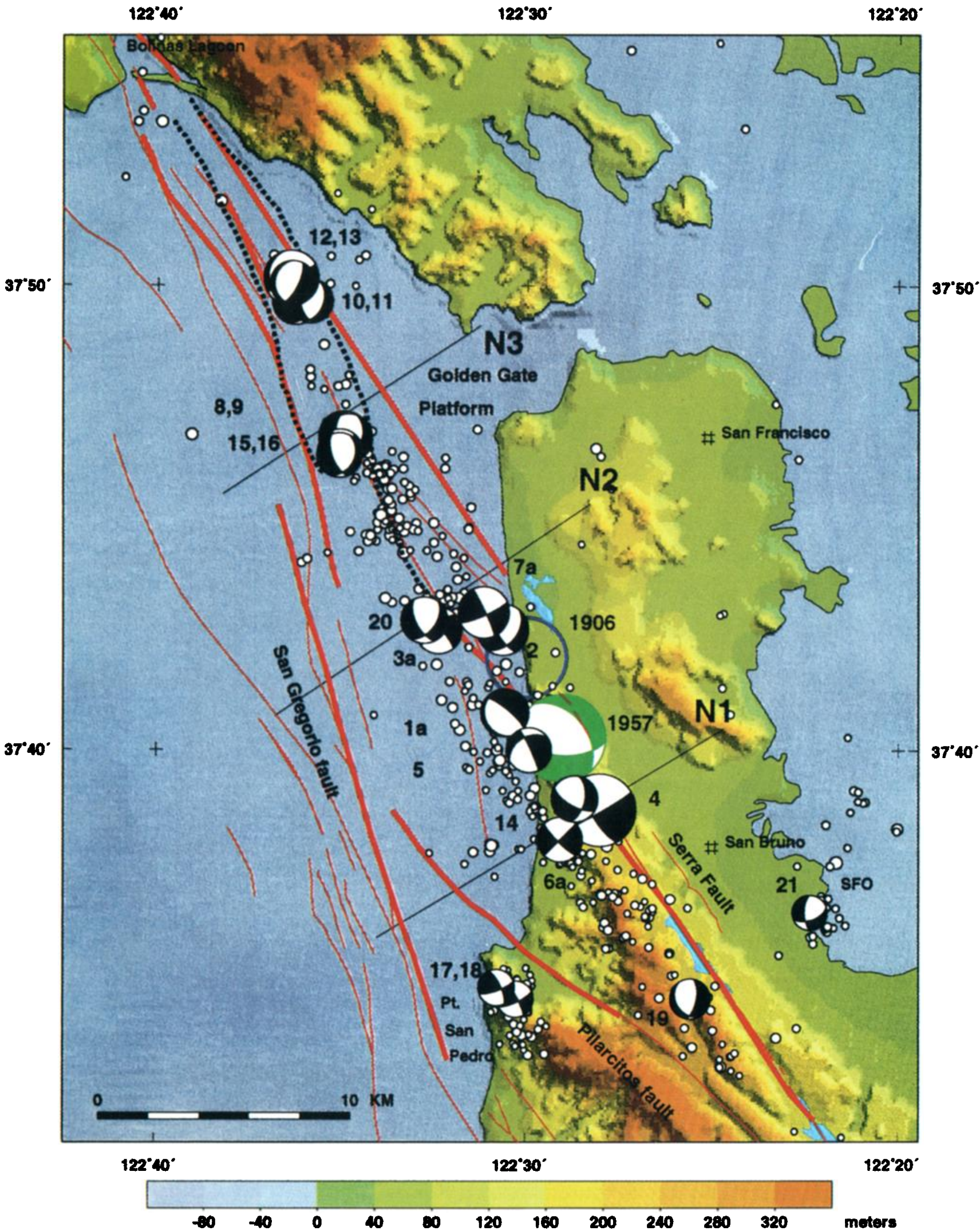

Plate 5. Seismicity and focal mechanisms in northernmost peninsula and Golden Gate platform area. Events are $M_{d} \geq 3.0$ events except for a few smaller events (see text). Event numbers refer to Table 1 and to first motion plots shown in Figure 4. New offshore geometry of the San Andreas and San Gregorio faults shown by heavy red lines (Plate 2). Thin red lines are Quaternary faults from Bortugno et al. [1992] (note the northernmost segment of the Serra reverse fault superimposed on the green focal mechanism for the 1957 earthquake). The heavy black dashed line marks the location of the "San Andreas" graben of Cooper [1973], from Plate 2. Thin black lines mark locations of cross sections shown in Plate 4a. 


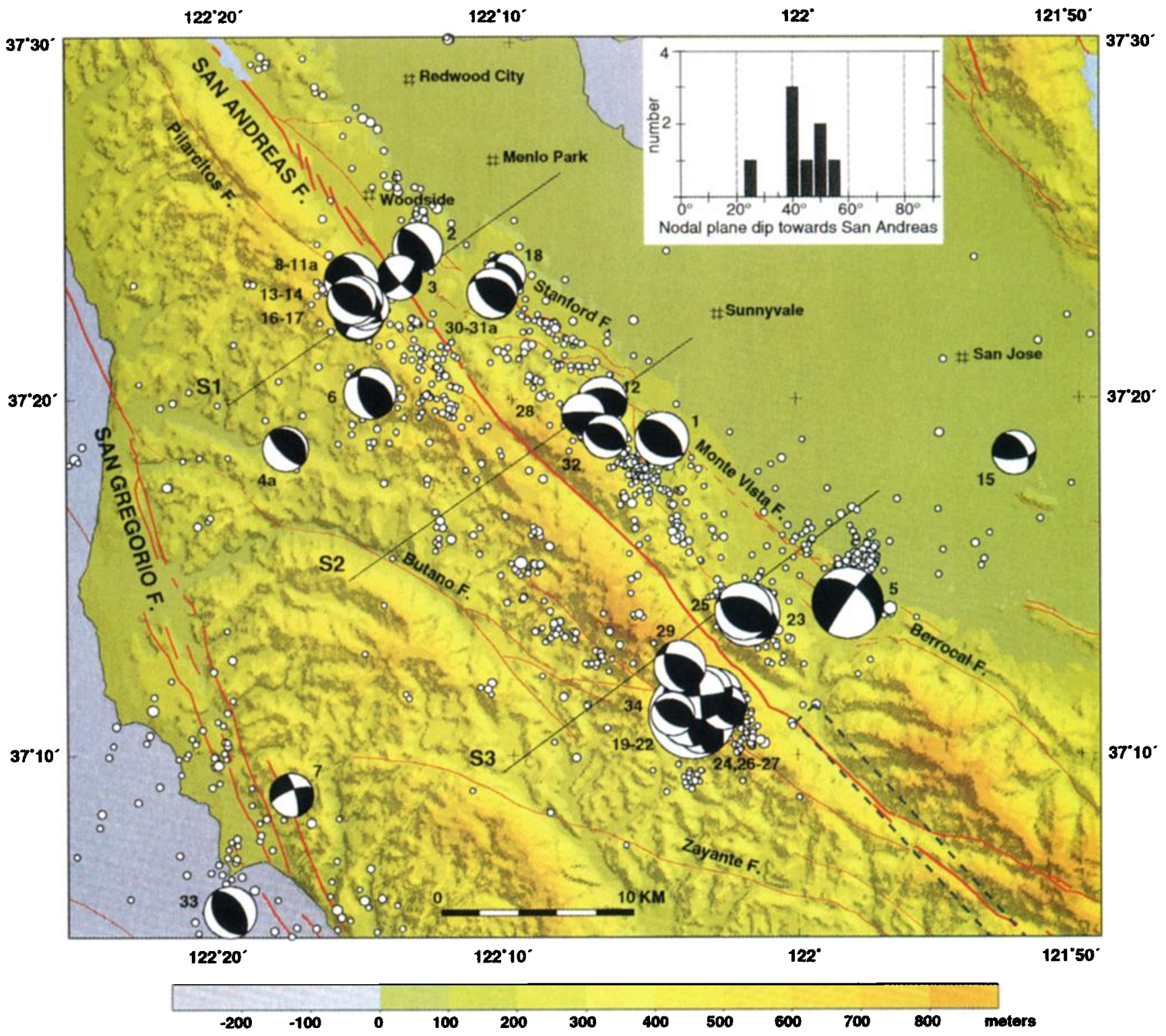

Plate 6. Seismicity and focal mechanisms of $M_{d} \geq 3.0$ events in the southern subarea. Event numbers refer to Table 2 and to first motion plots shown in Figure 5. Red lines are Quaternary faults from Bortugno et al. [1992], dashed red line on NE side of San Andreas between sections S2 and S3 represents the buried extension of the Monte Vista fault zone based on gravity modeling of Langenheim et al. [1997]. Surface projection of Loma Prieta rupture plane determined from geodetic modeling [Lisowski et al., 1997] indicated by dark blue dashed rectangle at bottom right.

escent zone $1.5-2.0 \mathrm{~km}$ wide coincides with the surface trace of the San Andreas fault and is defined between $\sim 3-\mathrm{km}$ and 12-km depth, most of the seismogenic part of the crust. The only significant activity located on the San Andreas fault proper in this southern zone of seismicity is the March 23, $1972, M_{d}=3.2$ event (event 3 in Plate 6) and its aftershocks located south of Woodside and shown on cross section S1 (between depths of 8 and $10 \mathrm{~km}$ ). Both the location and a right-lateral strike-slip focal mechanism for this event suggest that the San Andreas fault is approximately vertical to a depth of $10 \mathrm{~km}$ in this region. An approximately vertical attitude at depth can also be inferred from the $1.25-\mathrm{km}$-wide "gap" in seismicity at $\sim 10-\mathrm{km}$ depth on section S3 (Plate $4 \mathrm{~b}$ ). If this gap is interpreted as the maximum possible width of the San An- dreas fault zone, then the dip of the fault is constrained to be $>\sim 85^{\circ}$ to depths of $10 \mathrm{~km}$.

The microseismicity drops off between 7 and $10 \mathrm{~km}$ from the San Andreas fault but increases again to the SW in the vicinity of the San Gregorio fault. In cross section on both sides of the San Andreas there is a deepening of seismicity towards the fault (see S1 to S3 in Plate $4 \mathrm{~b}$ and composite section, Figure 6) suggestive of a large-scale flower structure in which moderately dipping thrusts at the surface steepen with depth to merge with a broad vertical shear zone [e.g., Sylvester, 1988]. In fact, NE of the San Andreas fault there is a series of mapped subparallel thrust faults that consistently dip to the SW, into the San Andreas. However, on the SW side of the San Andreas fault the structure is more complex and inconsistent with a simple 


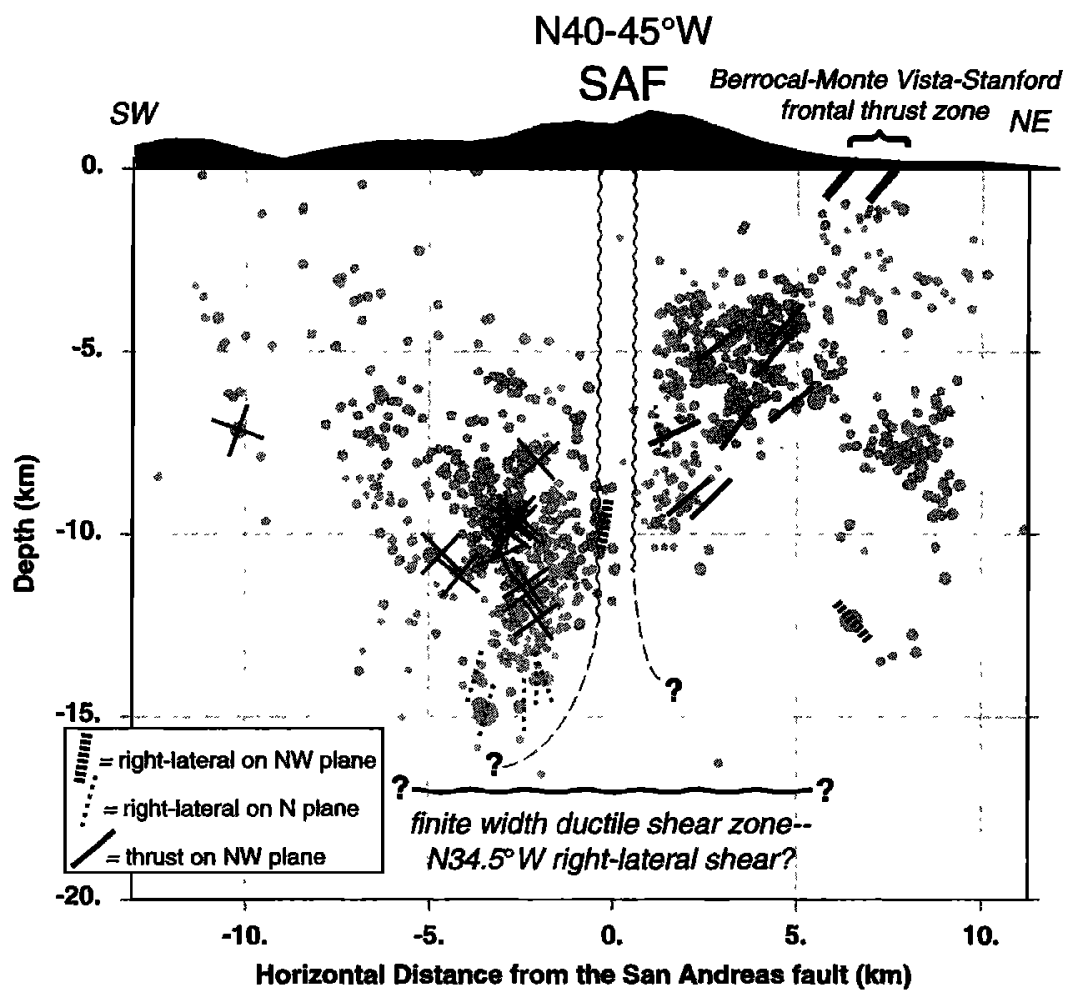

Figure 6. Interpretative cross section (composite from S1, S2, S3) across the San Andreas fault on the southern San Francisco Peninsula (topography along S2 shown in $2 \times$ vertical exaggeration). Wavy vertical lines denote "locked" aseismic San Andreas fault zone at depth. San Andreasward dips of nodal planes for $M_{d}$ $\geq 3.0$ "fault-normal compression" thrust/reverse events are shown by heavy solid lines NE of San Andreas. Short dashed lines represent dip of north striking right-lateral strike-slip planes, also consistent with fault normal compression. The heavy ruled line on the SW side of San Andreas fault gives dip of right-lateral plane for San Andreas event 3. The grey long-dashed line NE of San Andreas represents dip of right-lateral strike-slip plane striking parallel to San Andreas, event 15.

flower structure. Here much of the compressional deformation at the surface is accommodated by synclines and anticlines striking slightly oblique $\left(10^{\circ}-15^{\circ}\right.$ counterclockwise $)$ to the San Andreas. The one mapped late Quaternary fault on the SW side of the San Andreas, the Butano fault, actually dips steeply away from the San Andreas ( $>70^{\circ} \mathrm{SW}$ ) at the surface [Cummings et al., 1962]. Seismicity on the southernmost crosssection S3 (primarily Loma Prieta aftershocks) appears to delineate a steep SW-dipping zone directly adjacent to the San Andreas. The depth and geometry of this zone is similar to the geometry of the Loma Prieta mainshock rupture plane, the northern end of which is located just $5 \mathrm{~km}$ to the south (surface projection of rupture plane shown by dashed rectangle on Figure 10).

We used focal mechanisms to constrain the subsurface geometry of the thrust faulting on the NE side of the fault by selecting the NW-striking, SW-dipping nodal plane as the fault plane, consistent with the surface faulting. The inferred dips at depth (heavy solid lines on the composite cross-section across the fault in Figure 6 and histogram inset in Plate 6) range between $40^{\circ}$ and $55^{\circ} \mathrm{SW}$ for events between $4.7-$ and $9.5-\mathrm{km}$ depth (except event 2, with a dip of $25^{\circ}$ at 7.6-km depth). Because of the structural complexity on the SW side of the San Andreas the actual fault plane could not be inferred, so both possible nodal planes for the thrust/reverse events are shown in Figure 6 (the thin solid lines). These events also indicate generally moderate dips $\left(35^{\circ}-60^{\circ}\right)$. The moderately dipping thrust/ reverse fault planes inferred from focal mechanisms are consistent with the $35^{\circ}-70^{\circ}$ range of surface fault dips [Sorg and McLaughlin, 1975; McLaughlin and Clark, 1999] and suggest that generally planar faults with little or no steepening with depth persist throughout the seismogenic crust. The close proximity of some of the thrust/reverse planes to the vertical "aseismic" zone related to the main San Andreas fault at depth suggest that these fault planes intersect or merge at a high angle with the San Andreas. Both planar faults and the highangle intersection geometry at depth are inconsistent with simple flower structure models of thrust/reverse fault planes steepening with depth to merge with the strike-slip fault zone.

The focal mechanism data indicate an additional mode of failure in the crustal zone directly adjacent to the San Andreas fault. Focal mechanisms of some the deepest events seen on cross section S3 (primarily Loma Prieta aftershocks) indicate right-lateral strike-slip faulting on steep north striking planes (events 20-22, 26, and 27, planes marked by small dashes on a composite cross section shown in Figure 6). One pre-Loma Prieta event (event 7) on the NE side of the San Andreas also had a north striking right-lateral mechanism. This style of faulting is consistent with NE-compression (fault-normal) responsible for the thrust/reverse faults, but has no expression in surface geology.

The largest, pre-Loma Prieta, off-San Andreas earthquake in the southern zone of seismicity is a $M_{d}=4.5$ event in 1973 located about $7 \mathrm{~km} \mathrm{NE}$ of the San Andreas at a depth of 13.5 
$\mathrm{km}$ (event 5, Plate 6). It does not fit the general pattern of thrust/reverse faulting in response to fault-normal compression. The mechanism for this event is not well constrained, but indicates nearly pure right-lateral slip on a fault plane striking subparallel to the San Andreas fault and dipping $50^{\circ} \mathrm{NE}$, away from the San Andreas fault and opposite to the dips of the surface thrusts (plane shown by large dashes in Figure 6). The lack of pre- or post-Loma Prieta microseismicity in the vicinity of this large event on S3 (Plate 4b) does not allow delineation of a possible larger scale fault on which this $M=4.5$ event might have occurred.

A prominent cluster of seismicity $2-3 \mathrm{~km} \mathrm{SW}$ of the San Andreas fault in the northern part of the southern area shown on section S1 (Plate 4b) falls beneath the mapped trace of the Pilarcitos fault. These events occur at depths of $9-11 \mathrm{~km}$ and yield thrust/reverse mechanisms with dips of $31^{\circ}-57^{\circ} \mathrm{NE}$ for the plane dipping towards the San Andreas fault (Figure 6). Thus, despite hypocentral locations nearly directly below the surface trace of the Pilarcitos fault, it is unlikely, given their dips, that they represent activity on this approximately vertical fault as modelled by seismic [Parsons and Zoback, 1997] and magnetic [Jachens and Zoback, 1999] data on the northern Peninsula. Unpublished gravity modeling by one of us (R.C.J.) also indicates an approximately vertical dip for the Pilarcitos fault just $10 \mathrm{~km}$ north of $\mathrm{S} 1$.

\section{Tectonic Interpretation and Implications for Seismic Hazard}

\subsection{Strike-Slip Faulting Deformation}

Despite the persistent microseismicity in the San Francisco Peninsula area, both of the two major active strike-slip fault zones in the study area, the San Andreas and San Gregorio faults, are largely aseismic during the study period. Geologic data give ample evidence of Holocene slip on both the San Andreas and San Gregorio faults and indicate slip rates of 17-19 and $\sim 5 \mathrm{~mm} \mathrm{yr}^{-1}$, respectively [Working Group Report for Northern California Earthquake Potential, 1996]; therefore both faults are considered to be in a "locked" portion of their seismic cycle. A third strike-slip fault located between the two, the Pilarcitos fault, is also aseismic. As was noted previously, the Pilarcitos fault has been interpreted as an abandoned strike-slip portion of the plate boundary on the basis of geologic relationships [Page, 1990; Griscom and Jachens, 1989]. Furthermore, the Pilarcitos fault has Quaternary but no Holocene offset [Bortugno et al., 1992]. These facts, together with its more westerly strike than the San Andreas, lead us to suggest that its seismic potential is very low.

The aseismic character of the San Andreas fault persists to the southernmost portion of the study area, directly north of the Loma Prieta rupture (section S3, Plate 4b), despite the fact that this portion of the fault was subjected to some of the largest computed increases in Coulomb failure stress in the Bay area as a result of that $M_{w}=6.9$ event [Simpson, 1994; Simpson and Reasenberg, 1994]. Previously, Reasenberg and Simpson's [1992] analysis of post-Loma Prieta seismicity rate changes suggested seismicity increases along the San Andreas fault in this region; however, their $10-\mathrm{km}$-wide cells along the San Andreas fault really sampled the fault-normal compression-related seismicity occurring in the crust directly adjacent to the fault.

The lack of triggered slip on this section of the San Andreas fault lends support to the conclusion based on surface deformation and geodetic data [Prentice and Schwartz, 1991; Segall and Lisowski, 1990] that the Loma Prieta earthquake farther south occurred on a distinct fault plane, not on the San Andreas. Furthermore, the contrast between the high levels of Loma Prieta-triggered seismicity within the blocks adjacent to the San Andreas fault and the lack of triggered seismicity directly on the fault (Figure 6 and Plate 4b) suggests that the Coulomb failure strength of the San Andreas fault is greater than that of the surrounding crustal blocks in this early portion of the "locked" San Andreas seismic cycle. This high relative strength may be due to high normal stress across the San Andreas resulting from regional NE compression and insufficient pore pressure buildup within the fault zone to counteract it. If a system of pore pressure cells and seals exists within the fault zone and is responsible for an average overall low shear strength of the San Andreas fault [Blanpied et al., 1992; Byerlee, 1993; Rice, 1992; Sleep and Blanpied, 1992a, b], then seismicity and focal mechanism data presented here suggest that these cells and their lateral seals are probably restricted to a $\sim 1$ - to $1.5-\mathrm{km}$-wide zone at depth. In addition, the concentration of fault normal deformation in a 7 - to $10-\mathrm{km}$-wide zones on either side of the San Andreas suggests that ductile deformation at depth may be more distributed over a zone beneath the fault, as is indicated in Figure 6. Fault-normal compression in the southern San Francisco Peninsula is enhanced by the obliquity between the $\mathrm{N} 40^{\circ}-45^{\circ} \mathrm{W}$ striking San Andreas and a N34.$35^{\circ} \mathrm{W}$ oriented plate motion shear. Alternately, the width of deformation adjacent to the San Andreas may be simply a result of crustal weakening due to more extensive faulting as the blocks on either side accomodate deformation due to local bends in the fault system.

Although the present lack of seismicity on the San Andreas and San Gregorio faults provides no information on the timing of a future event, the seismicity and faulting patterns defined in this study may be useful for defining rupture segment boundaries, particularly for the San Andreas fault. Two types of major earthquakes are considered likely on the San Andreas fault in the study area, a repeat of the $M_{w}=7.81906$ earthquake and a repeat of the $1838 M_{w} \approx 6.8-7.5$ event on the peninsula [Working Group Report on California Earthquake Probabilities, 1990; Working Group on Northern California Earthquake Potential, 1996]. The normal faulting and abrupt right step ("releasing bend") offshore from San Francisco described here supports a likely segment boundary for a $M_{w} \approx$ 7.0 strike-slip event on the peninsula as suggested by the Working Group on Northern California Earthquake Potential [1996] largely on the basis of Thatcher et al.'s [1997] geodetically interpreted $\sim 2-\mathrm{m}$ reduction of 1906 slip and "bend" in the San Andreas occurring on the Golden Gate platform. The north end of rupture in the 1838 earthquake is unknown, but high intensities at Mission Delores in San Francisco lead Toppozada and Borchardt [1998] to locate the northern end of the rupture near San Francisco. Further support for the offshore right-step as a San Andreas segment boundary comes from observations of major strike-slip earthquake ruptures that terminate near releasing bends such as on the North Anatolian, southern San Andreas, and other fault systems [Sibson, 1985; Wesnousky, 1988; Barka and Kadinsky-Cade, 1988].

The 1906 earthquake indicates that the right stepover region does not always act as a segment boundary. This event not only ruptured through the offshore region but may have nucleated there as well. The best estimate for the epicenter of the 1906 
earthquake based on teleseismic data (and consistent with local timing observations and stopping of astronomical clocks) [Bolt, 1968] is $<5 \mathrm{~km}( \pm \sim 10 \mathrm{~km}$ [Boore, 1977]) south of the newly defined right step in the San Andreas fault offshore. The proximity of the 1906 epicenter to the right stepover offshore suggests that this structure may have exerted some control on localizing the nucleation of that event and be responsible for its bilateral rupture character. The 1995 Kobe earthquake epicenter also occurred in a 5-km right step in a right-lateral strikeslip fault system [Wald, 1996]. In that case the two offset rupture planes, defined by aftershock locations, surface faulting, and geodetic modeling, had slight dips toward each other $\left(\sim 85^{\circ}\right)$, and the hypocenter occurred at depth near the intersection of these two planes in the stepover region.

Redefinition of faulting patterns offshore have implications for the shaking hazard as well. The offshore 3-km right step in the San Andreas fault results in relocation of the main faulting strand $3 \mathrm{~km}$ closer to San Francisco. This NE shift in the locus of faulting may be significant for ground motion in the western portion of the city. Reducing the perpendicular distance from the fault from 5 to $2 \mathrm{~km}$ would result in an increase of $\mathrm{MM}$ intensity by about one unit, or roughly double the level of ground motion [Boatwright and Perkins, 1999].

\subsection{Extensional Deformation: Northernmost Peninsula and Golden Gate Platform}

Normal faulting, subsidence, and young basin formation offshore is likely related to the right-stepping geometry of the San Andreas and San Gregorio faults on the Golden Gate platform and probably explains why these faults and the crustal wedge between them lies below sea level. Nodal planes of the wellconstrained normal faulting mechanisms suggest potential fault planes striking between NNE and NNW, subparallel to the strike-slip faults; however, the low level of seismicity and small number of well-constrained mechanisms make it impossible to determine if all of this seismicity occurs on a discrete normal fault zone or zones offshore. Some of the best constrained normal faulting events occur at depths of 10-11 km, suggesting larger-scale extension (and potentially larger normal faults) than would be required to simply accomodate normal faulting within the 3-km San Andreas fault stepover. Normal faults restricted to the $3-\mathrm{km}$ stepover region should intersect at depths of $\sim 1.5-2.5 \mathrm{~km}$ (assuming dips between $45^{\circ}$ and $60^{\circ}$ ).

Further indication of distributed normal faulting in the northern section comes from the occurrence of wellconstrained normal faulting events up to $15 \mathrm{~km} \mathrm{NW}$ and $18 \mathrm{~km}$ $\mathrm{SE}$ of the actual San Andreas stepover. Master event relocation for the $1957 M=5.3$ normal faulting event (using the $1979 M=4.4$ San Andreas earthquake as the master event) places the 1957 earthquake $5-6 \mathrm{~km}$ south of the stepover. The significant along-strike extent of extensional tectonism NW and $\mathrm{SE}$ of the stepover region as well as the upper crustal scale of extension are compatible with 3-D elastic models of deformation adjacent to weak strike-slip fault zones underlain by finite width shear zones [Katzman et al., 1995; ten Brink et al., 1996]. Katzman et al.'s models of the vertical subsidence in the vicinity of a dilational stepover in a strike-slip fault demonstrated that a significant fraction $(50 \%)$ of the maximum subsidence (and extension) observed in the stepover can persist along strike for 2.5-4.0 times the stepover distance.

Geologic and seismic reflection data indicate that extension and basin development have been long-lived on the Golden
Gate platform. Cooper [1973] imaged a 4- to 8-km-wide basin between the San Andreas and the San Gregorio faults. Hole et al. [1996] found a maximum depth of $2 \mathrm{~km}$ for this basin. As was noted earlier, Cooper [1973] also delineated a distinct, somewhat sinuous 20-km-long, 2- to 3-km-wide "San Andreas" graben sitting on top of the broader basin; this youngest graben is shown by dashed lines in Plates 2 and 5 .

A Pliocene-Quaternary basin $\sim 3 \mathrm{~km}$ wide is exposed on land directly northeast of the San Andreas fault on the northernmost San Francisco Peninsula. This sequence of $\sim 3.0 \mathrm{Ma}$ to $0.4 \mathrm{Ma}$ shallow marine to estuarine deposits known as the Merced formation [Ingram, 1992] may be an older equivalent of the active pull-apart basin offshore. Jachens and Zoback [1999] have interpretated detailed gravity data on the northern peninsula to indicate a $2-$ to $3-\mathrm{km}$-wide, SE trending trough filled locally with more than a kilometer of young deposits, and bounded on the southwest by the onshore San Andreas fault and on the northeast by the onshore extension of the right step strand. The trough coincides closely with the narrow belt of outcropping Merced formation and shallows gradually to the southeast over a distance of $\sim 10 \mathrm{~km}$, just as the Merced formation thins to the southeast. Hengesh and Wakabayashi [1995] argued that the Merced formation was deposited in a marine basin developed within a pull-apart structure that has migrated with the Pacific plate (and currently lies offshore from the Golden Gate), an interpretation that is consistent with the geophysical data.

The Merced sedimentary trough, the basins observed in the offshore seismic reflection data, the $1957 M=5.3$ normal faulting earthquake, and the $\sim 30-\mathrm{km}$-long zone of normal faulting focal mechanisms suggest active normal faulting striking subparallel to the San Andreas and extending to at least $11-\mathrm{km}$ depth. However, the available data are insufficient to determine whether most of the extension occurs on one or more through-going, basin-bounding faults capable of generating surface-rupturing earthquakes on their own, or if the extension occurs on distributed small-scale normal faulting with slip triggered by large strike-slip faulting earthquakes on either the San Andreas or the San Gregorio fault. While the maximum magnitude of a potential normal fault based on a fault length of $25-30 \mathrm{~km}$ is only 6.0-6.5 [Scholz et al., 1986], proximity of such faulting to urban San Francisco $(3-10 \mathrm{~km}$ away) increases the importance of this potential hazard.

\subsection{Thrust/Reverse Deformation: Northernmost Peninsula}

The 3.0-0.4 Ma shallow marine Merced formation has been uplifted up to $200 \mathrm{~m}$ and compressionally deformed directly to the northeast of the San Andreas fault on the northernmost San Francisco Peninsula. This unit is folded (with dips as high as $70^{\circ}$ ) and is cut by the Serra thrust/reverse fault which is exposed for at least $15 \mathrm{~km}$ subparallel to and 1-2 km NE of the San Andreas fault (Plate 5) [Bonilla, 1964, 1994, 1996]. Cooper [1973] imaged similar steeply folded beds northeast of the San Andreas fault just a few kilometers offshore, which he interprets as a continuation of the compressional deformation of the Merced observed on land. The youngest documented movement on the Serra fault comes from trenches in which the fault cuts the late Pleistocene (130-70 ka) Colma formation [Hall, 1965, 1966]. At one locality the Serra fault displaces an undated A horizon soil that may be Holocene in age [Bonilla, 1994; Hengesh et al., 1996].

Hengesh and Wakabayashi [1995] propose that a change in deformational regime from extension to compression implied 
by first deposition, then deformation and uplift of the Merced formation is simply the result of effects of a migrating right step in the San Andreas fault that moves with the Pacific plate. Within the right step, extension results in deposition. After the right step passes by, the previously extended region is subjected to the regional fault normal compression in its wake. This hypothesis is inconsistent with the focal mechanism data in the northern peninsula, which indicate a combination of normal and right lateral strike-slip faulting at depth, even beneath the very young compressional deformation of the Merced. As was noted earlier, no thrust or reverse faulting mechanisms have been observed anywhere in the northern zone of seismicity, even for earthquakes as small as $M_{d}=2.0$. An alternate interpretation of the folding, faulting, and uplift of the Merced directly adjacent to the San Andreas fault is that they are due to a slight, local misalignment between the two offset strands of the San Andreas fault $\left(\sim 10^{\circ}\right.$ in the immediate vicinity of the right step) resulting in convergence with continued movement on the San Andreas system [Jachens et al., 1996; Jachens and Zoback, 1999]. The close proximity of the Serra fault to the San Andreas fault $(<1.5 \mathrm{~km})$ suggests it merges with or intersects the San Andreas fault at a shallow depth. Hence the Serra is probably not a deep-seated fault. This possibility and the observed normal faulting focal mechanisms leads us to propose that this young fault does not have primary seismogenic potential, although it may slip aseismically during major San Andreas events.

Wakabayashi and Moores [1988] have suggested that the NW trending Pilarcitos fault represents a thrust fault dipping NE into the San Andreas fault; hence this fault would have a trend similar to other thrust/reverse faults on the peninsula and could be considered potentially active. However, as noted previously, a seismic reflection, seismic tomography and magnetic data on the northern peninsula all indicate a approximately vertical dip for the Pilarcitos fault in the upper $6 \mathrm{~km}$ of the crust [Parsons and Zoback, 1997; Jachens and Zoback, 1999].

\subsection{Thrust/Reverse Deformation: Southern Peninsula}

Geologic evidence, topograpy, and the earthquake focal mechanisms indicates active thrust/reverse faulting within a zone 7-10 km wide on either side of the San Andreas fault on planes striking subparallel to the San Andreas. The overall strike of the San Andreas fault in the southern section is $\sim \mathrm{N} 45^{\circ} \mathrm{W}$, roughly $10^{\circ}-12^{\circ}$ westward of the plate motion vector at this latitude [Argus and Gordon, 1991]. Geodetic data indicate a total of $37-38 \mathrm{~mm} \mathrm{yr}^{-1}$ right-lateral slip in the $\mathrm{N} 34^{\circ}-$ $35^{\circ} \mathrm{W}$ plate motion direction over a $\sim 100$-km-wide region centered on the Bay area and limit the overall convergent (perpendicular) component to $\leq 3 \mathrm{~mm} \mathrm{yr}^{-1}$ [Lisowski et al., 1991; Williams et al., 1994]. However, in the area of the southernmost San Francisco Peninsula the average $10^{\circ}-12^{\circ}$ more westerly trend of the San Andreas fault should locally enhance this convergent component by $\sim 6.5 \mathrm{~mm} \mathrm{yr}^{-1}$, assuming that the $\sim 17 \mathrm{~mm} \mathrm{yr}^{-1}$ right-lateral plate boundary shear on the northern peninsula is accomodated through the bend by slip on a vertical San Andreas fault (which was not, however, the case in Loma Prieta). Since only a fraction of the regional $\leq 3 \mathrm{~mm}$ $\mathrm{yr}^{-1}$ convergence is likely accomodated adjacent to the San Andreas (the rest being accomodated in the East Bay [e.g., Graymer et al., 1994; Jayko and Lewis, 1996]) the total convergence across the Coast Ranges/Santa Cruz Mountains in the southernmost peninsula may be in the $6-8 \mathrm{~mm} \mathrm{yr}^{-1}$ range. Using geologic constraints on uplift, Valensise [1994] estimated a convergence rate in the Santa Cruz Mountains region of between 4 and $20 \mathrm{~mm} \mathrm{yr}^{-1}$.

Unfortunately, the microseismicity is so sparse that it is difficult to relate it in detail to specific mapped surface faults. Hypocenters of many of the events on the NE side of the San Andreas between sections S1 and S2 lie directly beneath the mapped frontal thrust fault system (Figure 6). If the causative fault planes (with dips in the range of $40-55^{\circ}$ at depths of 5-9.5 km) were projected up-dip, their surface traces would locate beneath the highly developed Santa Clara Valley, 3-5 km NE of the mapped frontal Monte Vista-Berrocal thrust system (Figures 6 and Plate 6). Gravity gradients within Santa Clara Valley have been interpreted as indicating possible NW trending faults with up to $130 \mathrm{~m}$ of vertical offset of bedrock [Finlayson et al., 1967], although variations in Franciscan bedrock geology may explain many of the gradients.

The best constrained fault attitude at depth is that of the Monte Vista thrust fault, part of the Monte Vista-Berrocal thrust system [Sorg and McLaughlin, 1975; McLaughlin and Clark, in press]. A newly extended near-surface trace of the Monte Vista fault based on geophysical data is shown by a red dashed trace in the region between S2 and S3 in Plate 6. This thrust places Franciscan bedrock over late Cenozoic sediments at the surface. Geologic mapping [Sorg and McLaughlin, 1975] and interpretation of gravity and aeromagnetic data [Langenheim et al., 1997] indicate a shallow dip for this fault ( $\left.\sim 17^{\circ} \mathrm{SW}\right)$ in the upper $1.3 \mathrm{~km}$ which abruptly steepens to about $60^{\circ}-70^{\circ}$. The geophysical interpretation constrains the fault geometry only in the upper $3 \mathrm{~km}$. However, simple downdip projection of this fault geometry (see blue line in Plate 4b, section S3) passes through some of the seismicity (including Loma Prieta aftershocks) at depths of 5-7 km in section S3. Although the projected plane of the Monte Vista thrust fault passes near the aftershock cluster that includes events 23 and 25 , its inferred $70^{\circ}$ dip is significantly steeper there than the $40^{\circ}-45^{\circ} \mathrm{SW}$ dips of these thrust events. Damage patterns resulting from the 1989 Loma Prieta earthquake were concentrated along mapped thrusts on the peninsula (including the Monte Vista fault). Langenheim et al. [1997] suggest a direct connection between the aftershocks (implying slip at depth on these faults) and the surface damage, but this connection can not be demonstrated in detail with the microseismicity.

Kovach and Beroza [1993] suggested continuity of mapped thrusts and microseismicity on the NE side of the San Andreas fault in the southern peninsula as indicating the potential for $M=6+$ thrust event. In fact, a $60-$ to $70-\mathrm{km}$-long zone of young thrust faults has been mapped along the NE margin of the Coast Ranges from just south of the southern end of Plate 6 to just north of the town of Woodside (the Berrocal, Monte Vista, and Stanford fault zones) [Aydin and Page, 1984; McLaughlin, 1974; McLaughlin and Clark, 1999]. Geomorphic evidence, including sag ponds, fault troughs, and stream diversions, suggests recent activity on these features [Rogers and Williams, 1974; Hitchcock et al., 1994]. Our seismicity data indicate that this entire $60-$ to $70-\mathrm{km}$ long zone of mapped frontal thrusts in underlain by thrust faulting microearthquakes. Convergence and uplift estimates along this zone are not well defined, however; the available data indicate they are consistent at about $\sim \leq 1 \mathrm{~mm} \mathrm{yr}^{-1}$ [Jayko and Lewis, 1996; R. J. McLaughlin, oral communication, 1998]. Thus at present there is no evidence that could rule out the possibility that the entire 60- to 70-km zone could fail in a single complex event (possibly analogous to the $1952 M_{w}=7.7$ Kern County event in south- 
ern California), although smaller thrust events along one of the frontal thrust zones $(M \approx 6)$ may be more likely.

Alternately, future thrust events could potentially occur on an unknown number of blind faults with no clear surface expression. Support for this suggestion comes not only from lack of correlation between microseismicity and the simple downward projection of mapped faults, but also from the lack of delineation of the Loma Prieta fault zone in pre-Loma Prieta seismicity. Careful analysis of microseismicity prior to several recent major earthquakes in California has failed to delineate the fault plane that ruptured (e.g., the $1983 M_{L}=6.7$ Coalinga [Eaton and Rymer, 1990]; $1989 M_{w}=6.9$ Loma Prieta [Olson and Hill, 1997]; and $1994 M_{w}=6.7$ Northridge [Hauksson et al., 1995].

\section{Conclusions}

Seismicity and focal mechanisms within a 10 - to $15-\mathrm{km}$-wide zone along the 100-km-long section of the San Andreas fault in the San Francisco Peninsula region indicate a prounounced along-strike variation from a zone of dominantly compressional tectonism in the south to a zone of dominanatly extensional tectonism in the north. Changes in San Andreas fault geometry accompany this change in tectonic style; the fault makes a broad $\left(\sim 10^{\circ}-12^{\circ}\right)$ left (restraining) bend on the southern peninsula and an abrupt 3-km right (releasing) step in the north, just offshore on the Golden Gate platform.

The northern and southern deformation zones are separated by a pronounced $\sim 15-\mathrm{km}$-long zone of seismic quiescence both on and off the San Andreas fault on the central peninsula. Seismicity in the southern area (from the north end of the 1989 $M=7.1$ Loma Prieta rupture to about the town of Woodside) occurs in 7- to 10-km-wide zones of deformation on both sides of the San Andreas fault; a vertical San Andreas fault zone is characterized by its nearly complete lack of seismicity. Focal mechanisms indicate thrust/reverse faulting with NE trending $P$ axes, indicating a pattern of fault-normal compression similar to the pattern of stress and deformation observed along the San Andreas fault throughout much of California [Mount and Suppe, 1987; Zoback et al., 1987]. This pattern of fault normal compression probably enhanced by the left bend in the fault in this area and is consistent with the young, high topography of the Santa Cruz Mountains/Coast Ranges. The thrust/reverse fault planes inferred from focal mechanisms suggest planar faults that intersect the San Andreas fault zone at a high angle $\left(35^{\circ}-55^{\circ}\right)$, rather than merging in a flower structure geometry.

In marked contrast, focal mechanisms on the northernmost peninsula and offshore on the Golden Gate indicate a combination of normal faulting and strike-slip seismicity in a diffuse zone west of the right-stepping Sani Andreas fault. Not a single thrust/reverse focal mechanism was observed down to $M_{d}=$ 1.5 , the approximate limit for reasonable focal sphere coverage. Normal faulting focal mechanisms occur within the newly defined 3-km right stepover in the San Andreas fault and at least $15 \mathrm{~km}$ along-strike both to the SE and NW. Here again, topography appears consistent with the ongoing tectonism: the San Andreas fault lies below sea level throughout most of the northern section, consistent with subsidence caused by extension and basin development.

Most of the seismicity occurs on secondary thrust and normal faults adjacent to the main San Andreas. The San Andreas fault proper, as elsewhere along the 1906 rupture, is largely aseismic, suggesting it is in a locked portion of its seismic cycle.
Two other Quaternary strike-slip fault zones on the peninsula, the San Gregorio and the Pilarcitos faults, are also currently aseismic. The San Andreas and San Gregorio faults have proven potential for $M=7$ and greater events, whereas the Pilarcitos fault appears to have low potential for slip and probably represents an abandoned portion of the plate boundary.

Our results have several implications for seismic hazard. The right-stepping geometry defined offshore for the San Andreas lends strong support for a proposed northern segment boundary for a "peninsula" San Andreas rupture [Working Group on Northern California Earthquake Potential, 1996]. Although the 1906 earthquake ruptured through this offshore region, it may have actually nucleated within the right stepover in the San Andreas fault, which may explain the bilateral nature of rupture of this event. The 1995 Kobe earthquake nucleated in a similar right step in a right-lateral strike-slip fault and also initiated a bilateral rupture [Wald, 1996]. The right step also relocates the main offshore San Andreas fault strand $3 \mathrm{~km}$ closer to downtown San Francisco, which could result in an increase of predicted intensity by about one unit, or roughly double the level of ground motion in the westernmost portion of the city [Boatwright and Perkins, 1999].

While the largest and most obvious seismic hazard for this part of the San Francisco Bay area remains a major strike-slip earthquake on the San Andreas fault, our analysis indicates the possibility of moderate $(M \approx 6+)$ earthquakes due to slip on subparallel normal and thrust faults. The $30 \mathrm{~km}$-long-zone of normal faulting seismicity (including a $M_{L}=5.3$ earthquake in 1957), together with geologic and seismic reflection evidence for large-scale, young basin development offshore, suggests the possibility of independent surface rupturing normal faulting events directly offshore from San Francisco. The potential for a $M=6+$ thrust/reverse faulting earthquake in the southern peninsula has previously been suggested by Kovach and Beroza [1993]. Our data indicate that a $60-$ to $70-\mathrm{km}-$ long mapped zone of Quaternary thrust faults on the NE side of the San Andreas fault is underlain by a continuous zone of thrust and reverse faulting microseismicity. However, specific fault planes at depth corresponding to surface faults can not be identified from the microseismicity. Further refinement of the potential reverse fault hazard in this region is hampered by this fact and by the possibility, as in case of Loma Prieta, of potentially active fault zones at depth that may have no clear surface expression or microseismic definition.

Acknowledgments. Travel times for the refraction shots on the CALNET stations were provided by Donna Eberhart-Phillips and Andy Michael. The paper greatly benefitted from careful reviews by Robert Simpson, Bob Smith, Diane Doser, David Oppenheimer, Uri ten Brink, Wayne Thatcher, and Victoria Langenheim. This paper is dedicated to the memory of Stanford University Geology Professor Ben Page, structural geologist extraordinaire, who probably forgot more about California Coast Range geology than we will ever know, and who always so willingly shared what he knew.

\section{References}

Argus, D. F., and R. G. Gordon, Current Sierra Nevada-North America motion from very long baseline interferometry; Implications for the kinematics of the western United States, Geology, 19, 1085-1088, 1991.

Aydin, A., and B. M. Page, Diverse Pliocene-Quaternary tectonics in a transform environment, San Francisco Bay region, California, Geol. Soc. Am. Bull., 95, 1303-1317, 1984.

Bakun, W. H., Seismic moments, local magnitudes, and coda-duration 
magnitudes for earthquakes in central California, Bull. Seismol. Soc Am., 74, 439-458, 1984

Bakun, W. H., Seismic activity of the San Francisco Bay region, Bull. Seismol. Soc. Am., in press, 1999.

Baranov, V., A new method for interpretation of aeromagnetic maps: Pseudo-gravimetric anomalies, Geophysics, 22, 359-383, 1957.

Barka, A. A., and K. Kadinsky-Cade, Strike-slip fault geometry in Turkey and its influence on earthquake activity, Tectonics, $7,663-$ 684, 1988.

Blake, M. C., Jr., D. G. Howell, and A. S. Jayko, Tectonostratigraphic terranes of the San Francisco Bay region, in Franciscan Geology of Northern California, Spec. Publ. 43, edited by M. C. Blake, pp. 5-22, Pac. Sect. Soc. of Econ. Paleontol. and Mineral., Los Angeles, Calif., 1984.

Blakely, R., and R. W. Simpson, Approximating edges of source bodies from magnetic or gravity anomalies, Geophysics, 51, 1494-1496, 1986.

Blanpied, M. L., D. Lockner, and J. D. Byerlee, An earthquake mechanism based on rapid sealing of faults, Nature, 358, 574-576, 1992.

Boatwright, J., and J. Perkins, The attenuation of seismic intensity for large strike-slip earthquakes, Bull. Seismol. Soc. Am., in press, 1999.

Bolt, B. A., The focus of the 1906 Califormia earthquake, Bull. Seismol. Soc. Am., 58, 457-471, 1968.

Bonilla, M. G., Bedrock-surface map of the San Francisco South quadrangle, California: San Francisco Bay Region Environment and Resources Planning Study, Basic Data Contribution 26, scale 1:31,680, U.S. Geol. Surv./U.S. Dep. of Housing and Urban Dev., Washington, D. C., 1964.

Bonilla, M. G., Serra fault zone, San Francisco Peninsula, California (abstract), Eos Trans. AGU, 75(44), Fall Meet. Suppl., 681, 1994.

Bonilla, M. G., Late Cenozoic folds and thrust faults, San Francisco South quadrangle, U.S. Geol. Surv. Open File Rep., 96-267, 36-38, 1996.

Boore, D. M., Strong-motion recordings of the California earthquake of April 18, 1906, Bull. Seismol. Soc. Am., 67, 561-577, 1977.

Bortugno, E. J., R. D. McJunkin, and D. L. Wagner, Map showing recency of faulting, San Francisco-San Jose quadrangle, California, Reg. Geol. Map Ser., map 51, sheet 5, map scale 1:250,000, Div. of Mines and Geol., Calif. Dep. of Conserv., Sacramento, 1992.

Brabb, E. E., and E. H. Pampeyan, Geologic map of San Mateo County, California, U.S. Geol. Surv. Misc. Invest. Ser. Map, I-1257-A, 1983.

Byerlee, J., Model for episodic flow of high pressure water in fault zones before earthquakes, Geology, 21, 303-306, 1993.

Catchings, R. D., and W. M. Kohler, Reflected seismic waves and their effect on strong shaking during the 1989 Loma Prieta, California, earthquake, Bull. Seismol. Soc. Am., 86, 1401-1416, 1996.

Clark, J. C., E. E. Brabb, H. G. Greene, and D. C. Ross, Geology of Point Reyes peninsula and implications for San Gregorio fault history, in Tectonics and Sedimentation Along the California Margin, Spec. Publ. 38, edited by J. K. Crouch, and S. B. Bachman, pp. 67-86, Pac. Sect., Soc. Econ. Paleontol. and Mineral., Los Angeles, Calif., 1984.

Cooper, A. K., Structure of the continental shelf west of San Francisco, California, U.S. Geol. Surv. Open File Rep., 1907, 65 pp., 1973.

Cordell, L., and V. J. S. Grauch, Mapping basement magnetization zones from aeromagnetic data in the San Juan basin, New Mexico, in The Utility of Regional Gravity and Magnetic Anomaly Maps, edited by W. J. Hinze, pp. 181-197, Soc. of Explor. Geophys., Tulsa, Okla., 1985.

Cummings, J. C., The Santa Clara Formation and possible postPliocene slip on the San Andreas fault in central California, in Proceedings of Conference on Geologic Problems of the San Andreas Fault System, edited by W. R. Dickinson and A. Grantz, Stanford Univ. Publ. Geol. Sci., 11, 191-207, 1968.

Cummings, J. C., R. M. Touring, and E. E. Brabb, Geology of the northern Santa Cruz Mountains, California, in Geologic Guide to the Gas and Oil Fields of Northern California, edited by O. E. Bowen Jr., Calif. Div. Mines Geol. Bull., 181, 179-220, 1962.

Eaton, J. P., Determination of amplitude and duration magnitudes and site residuals from short-period seismographs in northern California, Bull. Seismol. Soc. Am., 82, 533-579, 1992.

Eaton, J. P., and M. J. Rymer, Regional seismotectonic model for the southern Coast Ranges, in The Coalinga, California, Earthquake of May 2, 1983, U.S. Geol. Surv. Prof. Pap., 1487, 97-112, 1990.

Ellsworth, W. L., Three-dimensional structure of the crust and mantle beneath the island of Hawaii, Ph.D. thesis, Mass. Inst. of Technol., Cambridge, 1977.

Ellsworth, W. L., The San Andreas fault system, California, U.S. Geol. Surv. Prof. Pap., 1515, 153-185, 1990.

Finlayson, D. J., W. R. Hansen, and R. S. Ford, Evaluation of ground water resources, South Bay, Appendix A: Geology, Bull. 118-1, Calif. Dep. of Water Resour., Sacramento, 1967.

Graham, S. A., and W. R. Dickinson, Apparent offsets of on-land geologic features across the San Gregorio-Hosgri fault trend, in edited by E. A. Silver and W. R. Normark, eds., San GregorioHosgri fault zone, California, Spec. Publ. Calif. Div. Mines Geol., 137, 13-23, 1978.

Graymer, R. W., D. L. Jones, and E. E. Brabb, Preliminary geologic map emphasizing bedrock formations in Contra Costa County, California, U.S. Geol. Surv. Open File Rep., 94-622, 1994.

Griscom, A., and R. C. Jachens, Tectonic history of the north portion of the San Andreas fault system, California, inferred from gravity and magnetic anomalies, J. Geophys. Res., 94, 3089-3099, 1989.

Hall, N. T., Petrology of the type Merced Group, San Francisco Peninsula, California, M. S. thesis, 126 pp., Univ. of Calif., Berkeley, 1965.

Hall, N. T., Fleishhacker Zoo to Mussel Rock (Merced Formation); A Plio-Pleistocene nature walk, Calif. Div. Mines Geol. Min. Info. Serv., 19, S22-S25, 1966.

Hauksson, E. L., L. Jones, and K. Hutton, The 1994 Northridge earthquake sequence in California: Seismological and tectonic aspects, $J$. Geophys. Res., 100, 12,335-12,356, 1995.

Hengesh, J. V., and J. Wakabayashi, Dextral translation and progressive emergence of the Pleistocene Merced Basin and implications for timing of initiation of the San Francisco peninsula segment of the San Andreas Fault, in Recent Geologic Studies in the San Francisco Bay Area, Spec. Publ. 76, edited by E. M. Sangines, D. W. Andersen, and A. V. Buising, pp. 47-54, Pac. Sect. Soc. of Econ. Paleontol. and Mineral., Los Angeles, Calif., 1995.

Hengesh, J. V., J. M. Nolan, and J. Wakabayashi, Holocene displacement along the Serra fault, San Francisco peninsula, California (abstract), Eos Trans. $A G U$, 77(46), Fall Meet. Suppl., F744, 1996.

Hitchcock, C. S., K. I. Kelson, and K. C. Thompson, Geomorphic investigations of deformation along the northeastern margin of the Santa Cruz Mountains, U.S. Geol. Surv. Open File Rep., 94-187, 51 pp., 1994.

Holbrook, W. S., T. M. Brocher, U. S. ten Brink, and J. A. Hole, Crustal structure of a transform plate boundary: San Francisco Bay and the central California continental margin, J. Geophys. Res., 101, 22,311-22,334, 1996.

Hole, J. A., W. S. Holbrook, S. L. Klemperer, U. S. Ten Brink, and T. M. Brocher, Crustal structure in the San Francisco Bay area from wide-angle seismic refraction data (abstract), Eos Trans. $A G U$, 74(43), Fall Meet. Suppl., 445, 1993.

Hole, J. A., H. Thybo, and S. L. Klemperer, Seismic reflections from the near-vertical San Andreas fault, Geophys. Res. Lett., 23, 237-240, 1996.

Ingram, B. L., Paleoclimatic and paleoceanographic studies of estuarine and marine sediments using strontium isotopes, $\mathrm{Ph} . \mathrm{D}$. thesis, 236 pp., Stanford Univ., Stanford, Calif., 1992.

Jachens, R. C., and A. Griscom, Geologic and geophysical setting of the 1989 Loma Prieta earthquake, California, inferred from gravity and magnetic anomalies, in The Loma Prieta Earthquake of October 1989-Geologic Setting and Crustal Structure, edited by R. E. Wells and J. Vidale, U.S. Geol. Surv. Prof. Pap., 1550-E, in press, 1999.

Jachens, R. C., and M. L. Zoback, The San Andreas fault in the San Francisco Bay region, California: Structure and kinematics of a young plate boundary, Int. Geol. Rev., in press, 1999.

Jachens, R. C., C. W. Roberts, and M. L. Zoback, Total offset and right-stepping geometry of the San Francisco Peninsula segment of the San Andreas fault, California, defined by aeromagnetic anomalies (abstract), Eos Trans. $A G U, 77(46)$, Fall Meet. Suppl., F742, 1996.

Jaumé, S. C., and L. R. Sykes, Evolution of moderate seismicity in the San Francisco Bay region, 1850 to 1993: Seismicity changes related to the occurrence of large and great earthquakes, J. Geophys. Res., 101, 765-789, 1996

Jayko, A. S., and S. D. Lewis (Principal Compilers), Toward assessing the seismic risk associated with blind faults, San Francisco Bay Region, California, U.S. Geol. Surv. Open File Rept. 96-267, 188 pp., 1996. 
Katzman, R., U. S. ten Brink, and J. Lin, Three-dimensional modeling of pull-apart basins: Implications for the tectonics of the Dead Sea basin, J. Geophys. Res., 100, 6295-6312, 1995.

Klein, F. W., User's guide to HYPOINVERSE, a program for VAX computers to solve for earthquake locations and magnitudes, U.S. Geol. Surv. Open File Rep., 89-314, 44 pp., 1989.

Kovach, R. L., and G. C. Beroza, Seismic potential from reverse faulting on the San Francisco peninsula, Bull. Seismol. Soc. Am., 83, $597-602,1993$.

Langenheim, V. E., K. M. Schmidt, and R. C. Jachens, Coseismic deformation during the 1989 Loma Prieta earthquake and rangefront thrusting along the southwestern margin of the Santa Clara Valley, California, Geology, 25, 1091-1094, 1997.

Lisowski, M., J. C. Savage, and W. H. Préscott, The velocity field along the San Andreas fault in central and southern California, J. Geophys. Res., 96, 8369-8389, 1991.

Lisowski, M., M. Murray, and J. L. Svarc, Geodetic measurements of coseismic horizontal deformation, U.S. Geol. Surv. Prof. Pap., 1550-A, A81-A95, 1997.

Louderback, G. D., Central California earthquakes of the 1830's, Bull. Seismol. Soc. Am., 37, 33-74, 1947.

Marsden, R., M. L. Zoback, D. Dreger, B. Julian, J. Olson, and T. M. Parsons, M5.3 normal faulting event adjacent to the San Andreas fault on the San Francisco peninsula (abstract), Eos Trans. $A G U$, 76(46), Fall Meet. Suppl., F423, 1995.

McCulloch, D. S., Regional geology and hydrocarbon potential of offshore central California, in Geology and Resource Potential of the Continental Margin of Western North America and Adjacent Ocean Basins-Beaufort Sea to Baja California, edited by D. W. Scholl, A. Grantz, and J. G. Vedder, pp. 353-401, Circum-Pac. Counc. for Energy and Miner. Resour., Houston, Tex., 1987.

McLaughlin, R. J., The Sargent-Berrocal fault zone and its relation to the San Andreas fault system in the southern San Francisco Bay region and Santa Clara Valley, U.S. Geol. Surv. J. Res., 2, 593-598, 1974.

McLaughlin, R. J., and J. C. Clark, Geologic setting of the October 17, 1989, Loma Prieta earthquake, in The Loma Prieta Earthquake of October 1989-Geologic Setting and Crustal Structure, edited by R. E. Wells and J. Vidale, U.S. Geol. Surv. Prof. Pap., 1550-E, in press, 1999.

McLaughlin, R. J., W. V. Sliter, D. H. Sorg, P. C. Russell, and A. M. Sarna-Wojcicki, Large-scale right-slip displacement on the east San Francisco Bay region fault system, California: Implications for location of late Miocene to Pliocene Pacific plate boundary, Tectonics, 14, 1-18, 1996.

Mount, V. S., and J. Suppe, State of stress near the San Andreas fault: Implications for wrench tectonics, Geology, 15, 1142-1146, 1987.

Murphy, J. M., R. D. Catchings, and W. M. Kohler, Data report for 1991 active-source seismic profiles in the San Francisco Bay area, California, U.S. Geol. Surv. Open File Rep., 92-570, 45 pp., 1992.

Olson, J. A., and D. P. Hill, Seismicity in the southern Santa Cruz Mountains during the 20-year period before the earthquake, in The Loma Prieta, Califomia, Earthquake of October 17, 1989: Earthquake Occurrence-Preseismic Observations, U.S. Geol. Surv. Prof. Pap., 1550-C, C3-C16, 1997.

Olson, J. A., and M. L. Zoback, Source character of microseismicity in the San Francisco Bay block, California, and implications for seismic hazard, Bull. Seismol. Soc. Am., 88, 543-555, 1998.

Oppenheimer, D. H., Aftershock slip behavior of the 1989 Loma Prieta earthquake, Geophys. Res. Lett., 17, 1199-1202, 1990.

Oppenheimer, D., F. W. Klein, J. P. Eaton, and F. Lester, The Northern California Seismic Network Bulletin January-December 1992, U.S. Geol. Surv. Open File Rep., 93-578, 45 pp., 1993. (Available at http:/quake.geo.berkeley.edu/ncsn/bulletin.ps).

Page, B. M., Modes of Quaternary tectonic movement in the San Francisco Bay region, California, in Proceedings of the Conference on Earthquake Hazards in the Eastern San Francisco Bay Area, Spec. Publ. Calif. Div. Mines Geol., 62, 1-10, 1982.

Page, B. M., Evolution and complexities of the transform system in California, U.S.A., Ann. Tect., $N$, 53-69, 1990.

Page, B., Tectonic setting of the San Francisco Bay region, in Proceedings of the Second Conference on Earthquake Hazards in the Eastern San Francisco Bay Area, Spec. Publ. Calif. Div. Mines Geol., 113, 1-7, 1992.

Parsons, T., and M. L. Zoback, Three-dimensional upper crustal ve- locity structure beneath San Francisco Peninsula, California, J. Geophys. Res., 102, 5473-5490, 1997.

Prentice, C. A., and D. P. Schwartz, Re-evaluation of 1906 surface faulting, geomorphic expression, and seismic hazard along the San Andreas fault in the southern Santa Cruz Mountains, Bull. Selsmol. Soc. Am., 81, 1424-1479, 1991.

Reasenberg, P. A. (Ed.), The Loma Prieta, California, earthquake of October 17, 1989-Aftershocks and postseismic effects, U.S. Geol. Surv. Prof. Pap., 1550-D, 310 pp., 1997.

Reasenberg, P. A., and D. H. Oppenheimer, FPFIT, FPPLOT, and FPPAGE: FORTRAN computer programs for calculating and displaying earthquake focal mechanisms, U.S. Geol. Surv. Open File Rep., 85-739, 109 pp., 1985.

Reasenberg, P. A., and R. W. Simpson, Response of regional seismicity to the static stress change produced by the Loma Prieta earthquake, Science, 255, 1687-1690, 1992.

Rice, J. R., Fault stress states, pore pressure distributions, and the weakness of the San Andreas fault, in Fault Mechanics and Transport Properties in Rocks (The Brace Volume), edited by B. Evans and T.-F. Wong, pp. 475-503, Academic, San Diego, Calif., 1992.

Roberts, C. W., and R. C. Jachens, Isostatic residual gravity map of the San Francisco Bay area, California, U.S. Geol. Surv. Map GP-1006, scale 1:286,500, 1993.

Roecker, S. W., Seismicity and tectonics of the Pamir-Hindu Kush region of central Asia, Ph.D. thesis, 207 pp., Mass. Inst. of Technol., Cambridge, 1981.

Rogers, T. H., and J. W. Williams, Potential seismic hazards in Santa Clara county, California, Spec. Rep., Calif. Div. Mines Geol., 107, 39 pp., 1974.

Scholz, C. H. C. A. Aviles, and S. G. Wesnousky, Scaling differences between large interplate and intraplate earthquakes, Bull. Seismol. Soc. Am., 76, 65-70, 1986.

Segall, P., and M. Lisowski, Surface displacements in the 1906 San Francisco and 1989 Loma Prieta earthquakes, Science, 250, 12411244, 1990.

Sibson, R. H., Stopping of earthquake ruptures at dilational fault jogs, Nature, 316, 248-251, 1985.

Simpson, G. D., S. C. Thompson, J. S. Noller, and W. R. Lettis, The northern San Gregorio fault zone: Evidence for the timing of late Holocene earthquakes near Seal Cove, California, Bull. Seismol. Soc. Am., 87, 1158-1170, 1997.

Simpson, R. W. (Ed.), The Loma Prieta, California earthquake of October 17, 1989-Teconic processes and models, U.S. Geol. Surv. Prof. Pap., 1550-F, 131 pp., 1994.

Simpson, R. W., and P. A. Reasenberg, Earthquake-induced static stress changes on central California faults, U.S. Geol. Surv. Prof. Pap., 1550-F, 55-89, 1994.

Sleep, N. H., and M. L. Blanpied, Creep, compaction and the weak rheology of major faults, Nature, 359, 687-692, 1992a.

Sleep, N. H., and M. L. Blanpied, Ductile creep and compaction: A mechanism for transiently increasing fluid pressure in mostly sealed fault zones, Pure Appl. Geophys., 143, 9-40, $1992 \mathrm{~b}$.

Sorg, D. H., and R. J. McLaughlin, Geologic map of the SargentBerrocal fault zone between Los Gatos and Los Altos Hills, Santa Clara County, California, U.S. Geol. Surv. Misc. Field Inv. Map $M F$-643, scale 1:24,000, 1975.

Spudich, P., The Loma Prieta, California, earthquake of October 17, 1989-Main shock characteristics, U.S. Geol. Surv. Prof. Pap., 1550-A. 297 pp. 1996.

Sylvester, A. G., Strike-slip faults, Geol. Soc. Am. Bull., 100, 16661703,1988 .

ten Brink, U. S., R. Katzman, and J. Lin, Three-dimensional models of deformation near strike-slip faults, J. Geophys. Res., 101, 16,20516,220, 1996.

Thatcher, W., G. Marshall, and M. Lisowski, Resolution of fault slip along the 470-km-long rupture of the great 1906 San Francisco earthquake and its implications, J. Geophys. Res., 102, 5353-5367, 1997.

Toppozada, T. R., and G. Borchardt, Re-evaluation of the 1836 "Hayward fault" and the 1838 San Andreas fault earthquakes, Bull. Seismol. Soc. Am., 88, 140-159, 1998.

Tuttle, M. P., and L. R. Sykes, Re-evaluation of several large historic earthquakes in the vicinity of the Loma Prieta and Peninsular segments of the San Andreas fault, California, Bull. Seismol. Soc. Am., $82,1802-1820,1992$. 
Uhrhammer, R. A., The Pacifica earthquake of April 28, 1979, Bull. Seismol. Soc. Am., 71, 1161-1172, 1981.

Valensise, G., Geologic assessment of the relative contribution of strike-slip faulting, reverse-slip faulting, and bulk squeezing in the creation of the central Santa Cruz Mountains, California, U.S. Geol. Surv. Prof. Pap., 1550-F, 23-47, 1994.

Wagner, D. L., E. J. Bortugno, and R. D. McJunkin, Geologic map of the San Francisco-San Jose quadrangle, California, Reg. Geol. Map Ser., map 5A, scale 1:250,000, Div. of Mines and Geol., Calif. Dep. of Conserv., Sacramento, 1991.

Wakabayashi, J., and E. Moores, Evidence for collision of the Salinian block with the Franciscan subduction zone, California, J. Geol., 96, 245-253, 1988.

Wald, D. J., Slip history of the 1995 Kobe, Japan, earthquake determined from strong-motion, teleseismic, and geodetic data, $J$. Phys. Earth, 44, 489-503, 1996.

Wald, D. J., H. Kanamori, D. V. Helmberger, and T. H. Heaton, Source study of the 1906 San Francisco earthquake, Bull. Seismol. Soc. Am., 83, 981-1019, 1993.

Wells, R., and J. Vidale (eds.), The Loma Prieta, California, earthquake of October 17, 1989-Geologic setting and crustal structure, U.S. Geol. Surv. Prof. Pap., 1550-E, in press, 1999.

Wesnousky, S. G., Seismological and structural evolution of strike-slip faults, Nature, 335, 340-343, 1988.

Williams, S. D. P., Current motion on faults of the San Andreas system in central California inferred from recent GPS and terrestrial survey measurements, Ph.D. thesis, 282 pp., Univ. of Durham, Durham, England, 1995.
Williams, S. D. P., J. L. Svarc, M. Lisowski, and W. H. Prescott, GPS measured rates of deformation in the northern San Francisco Bay region, California, 1990-1993, Geophys. Res. Lett., 21, 1511-1514, 1994.

Working Group on California Earthquake Probabilities, Probabilites of large earthquakes in the San Francisco Bay region, California, U.S. Geol. Surv. Circ., 1053, 51 pp., 1990.

Working Group on Northern California Earthquake Potential, Database of potential sources for earthquakes larger than magnitude 6 in northern California, U.S. Geol. Surv. Open File Rep., 96-705, 57 pp., 1996. (Available at http://quake.wr.usgs.gov/hazprep/NCEP)

Zoback, M. D., et al., New evidence on the state of stress of the San Andreas fault system, Science, 238, 1105-1111, 1987.

Zoback, M. L., and R. C. Jachens, Right-stepping geometry of the San Andreas and San Gregorio faults and persistent normal faulting in the 1906 San Francisco earthquake epicentral area (abstract), Eos Trans. $A G U, 77(46)$, Fall Meet. Suppl., F742, 1996.

R. C. Jachens and M. L. Zoback, Mail Stop 977, U.S. Geological Survey, 345 Middlefield Road, Menlo Park, CA 94025. (jachens@fourier.wr.usgs.gov; zoback@andreas.wr.usgs.gov)

J. A. Olson, Trimble Navigation Company, Sunnyvale, CA 94401. (jean_olson@trimble.com)

(Received December 15, 1997; revised August 18, 1998; accepted October 13, 1998.) 